\title{
Five Reasons to Consider Phytophthora infestans a Reemerging Pathogen
}

\author{
W. E. Fry, P. R. J. Birch, H. S. Judelson, N. J. Grünwald, G. Danies, K. L. Everts, A. J. Gevens, B. K. Gugino, \\ D. A. Johnson, S. B. Johnson, M. T. McGrath, K. L. Myers, J. B. Ristaino, P. D. Roberts, G. Secor, and C. D. Smart
}

First, fifth, and twelfth authors: Cornell University, Section of Plant Pathology and Plant-Microbe Biology, 334 Plant Science Bldg., Ithaca, NY 14850; second author: Division of Plant Sciences, University of Dundee at James Hutton Institute, Invergowrie, Dundee, DD2 4DA, UK; third author: Department of Plant Pathology and Microbiology, University of California, Riverside 92521; fourth author: Horticultural Crops Research Laboratory, United States Department of Agriculture-Agricultural Research Service, 3420 NW Orchard Ave., Corvallis, OR 97330; sixth author: Plant Pathology Department, University of Maryland, 27664 Nanticoke Rd., Salisbury 21801; seventh author: University of Wisconsin Department of Plant Pathology, 1630 Linden Dr., Madison 53706-1598; eighth author: Department of Plant Pathology and Environmental Microbiology, College of Agricultural Sciences, The Pennsylvania State University, 219 Buckhout Lab, University Park 16802; ninth author: Department of Plant Pathology, Washington State University, PO Box 646430, Pullman; tenth author: University of Maine Cooperative Extension, 57 Houlton Road, Presque Isle 04769; eleventh author: Section of Plant Pathology and Plant-Microbe Biology, Cornell University, Long Island Horticultural Research \& Extension Center, Riverhead, NY 11901-1098; thirteenth author: Department of Plant Pathology, Room 2419 Gardner Hall, NC State University, Raleigh 27695; fourteenth author: Department of Plant Pathology, University of Florida, Southwest Florida Research and Education Center, 2685 SR 29 N, Immokalee 34142-9515; fifteenth author: Department of Plant Pathology, North Dakota State University, 328 Walster Hall, Dept. 7660, PO Box6050, Fargo 58108-6050; and sixteenth author: Section of Plant Pathology and Plant-Microbe Biology, Cornell University, Barton Lab, NYSAES, 630 West North Street, Geneva, NY 14456. Accepted for publication 2 March 2015.

\begin{abstract}
Fry, W. E., Birch, P. R. J., Judelson, H. S., Grünwald, N. J., Danies, G., Everts, K. L., Gevens, A. J., Gugino, B. K., Johnson, D. A., Johnson, S. B., McGrath, M. T., Myers, K. L., Ristaino, J. B., Roberts, P. D., Secor, G., and Smart, C. D. 2015. Five reasons to consider Phytophthora infestans a reemerging pathogen. Phytopathology 105:966-981.

Phytophthora infestans has been a named pathogen for well over 150 years and yet it continues to "emerge", with thousands of articles published each year on it and the late blight disease that it causes. This review explores five attributes of this oomycete pathogen that maintain this constant attention.

First, the historical tragedy associated with this disease (Irish potato famine) causes many people to be fascinated with the pathogen. Current technology now enables investigators to answer some questions of historical significance. Second, the devastation caused by the pathogen continues to appear in surprising new locations or with surprising new intensity. Third, populations of $P$. infestans worldwide are in flux, with changes that have major implications to disease management. Fourth, the genomics revolution has enabled investigators to make tremendous progress in terms of understanding the molecular biology (especially the pathogenicity) of $P$. infestans. Fifth, there remain many compelling unanswered questions.
\end{abstract}

The late blight disease caused by Phytophthora infestans is regarded as one of the most devastating of plant diseases and certainly the most devastating disease of potato (Agrios 2005). For potato, the disease has been estimated to cause more than $\$ 6$ billion in losses and management costs annually (Haverkort et al. 2008). Not only is potato foliage destroyed (Fig. 1A) but potato tubers can also become infected (Fig. 1B). The disease is at least as destructive on tomato as it is on potato (Fig. 2). It can destroy plants rapidly, and is sometimes reported to kill plants in a matter of hours (see below). The tomato plants depicted in Figure 2 have been nearly completely destroyed by late blight, and were destined to be removed shortly after this picture was taken. Much fungicide is used to protect potato and tomato; for example, in the United States in 2001 alone, more than 2000 tons of fungicides were used on potato to suppress this disease (Anonymous 2004).

Asexual reproductive cycles (Fig. 3) are responsible for devastating epidemics. As an oomycete, $P$. infestans produces sporangia (Fig. 3C) which can germinate directly (to produce a germ tube) or indirectly to produce zoospores (Fig. 3D). After a short period of motility (minutes to hours), the zoospores encyst and germinate via a germ tube. If the zoospores are on host tissue, the germ tube can penetrate the host and initiate infections (Fig. 3E). Sporulation occurs

Corresponding author W. E. Fry; E-mail address: wef1@cornell.edu from lesions and is stimulated by moist conditions at moderate temperatures $\left(15\right.$ to $\left.22^{\circ} \mathrm{C}\right)$. A single lesion can produce several hundred thousand sporangia (Fig. 3A), which are aerially dispersed (Fig. 3C). Asexual reproduction can also lead to the development of clonal lineages. The individuals in a clonal lineage are all derived from a single recombination event, and differ from each other only by mutation or mitotic recombination. Members of the same clonal lineage are generally phenotypically similar to each other.

Given the devastating potential of this pathogen, it's easy to understand the attention it receives. However, the pathogen and disease have emerged and reemerged so many times that it might be logical to conclude that nothing new could be said about this disease. And yet, much continues to be said (and written). A search on Google Scholar for "late blight of potato" returned 61,100 articles, with 16,700 since 2010. Obviously, the world continues to devote much attention to this pathogen and disease.

We think there are several attributes that maintain the visibility of this pathogen (and its disease), thus causing it to be always "reemerging". Because this review cannot be totally comprehensive, we have identified five attributes that we believe are responsible for the fact that this pathogen and its disease remain "emerging" and, thus, of intense interest to growers, home gardeners, historians, and scientists.

1. The historical tragedy associated with this disease (Irish potato famine) causes many people to be fascinated with the pathogen. Current technology now enables investigators to answer some questions of historical significance. 
2. The devastation caused by the pathogen continues to appear in surprising new locations or with surprising new intensity.

3. Populations of $P$. infestans worldwide are in flux, with changes that have major implications to disease management.

4. The genomics revolution has enabled investigators to make tremendous progress in terms of understanding the hostpathogen interactions.

5. There are many compelling unanswered questions.

\section{CURRENT QUESTIONS OF HISTORICAL SIGNIFICANCE}

The availability of current genomic and next-generation sequencing resources, culture collections, and herbarium collections have converged to enable investigators to apply additional data and insight to controversies concerning the center of origin of $P$. infestans and to resolving the identity of the genotypes of $P$. infestans responsible for the Irish potato famine.

Center of origin. The disease appeared very suddenly in the mid-19th century. Where did the pathogen come from? The initial assumption was that $P$. infestans originated in the Andes of South America along with the potato (Berkeley 1846; Jones et al. 1912). However, there were some doubters-among them was Donald Reddick of Cornell University (Reddick 1928). Reddick felt that if $P$. infestans had been endemic to South America, it would have been observed there by European botanists, but he found no such reports. Eleven years later, and based partially on the fact that the native species of Solanum in Mexico are largely resistant to P. infestans,
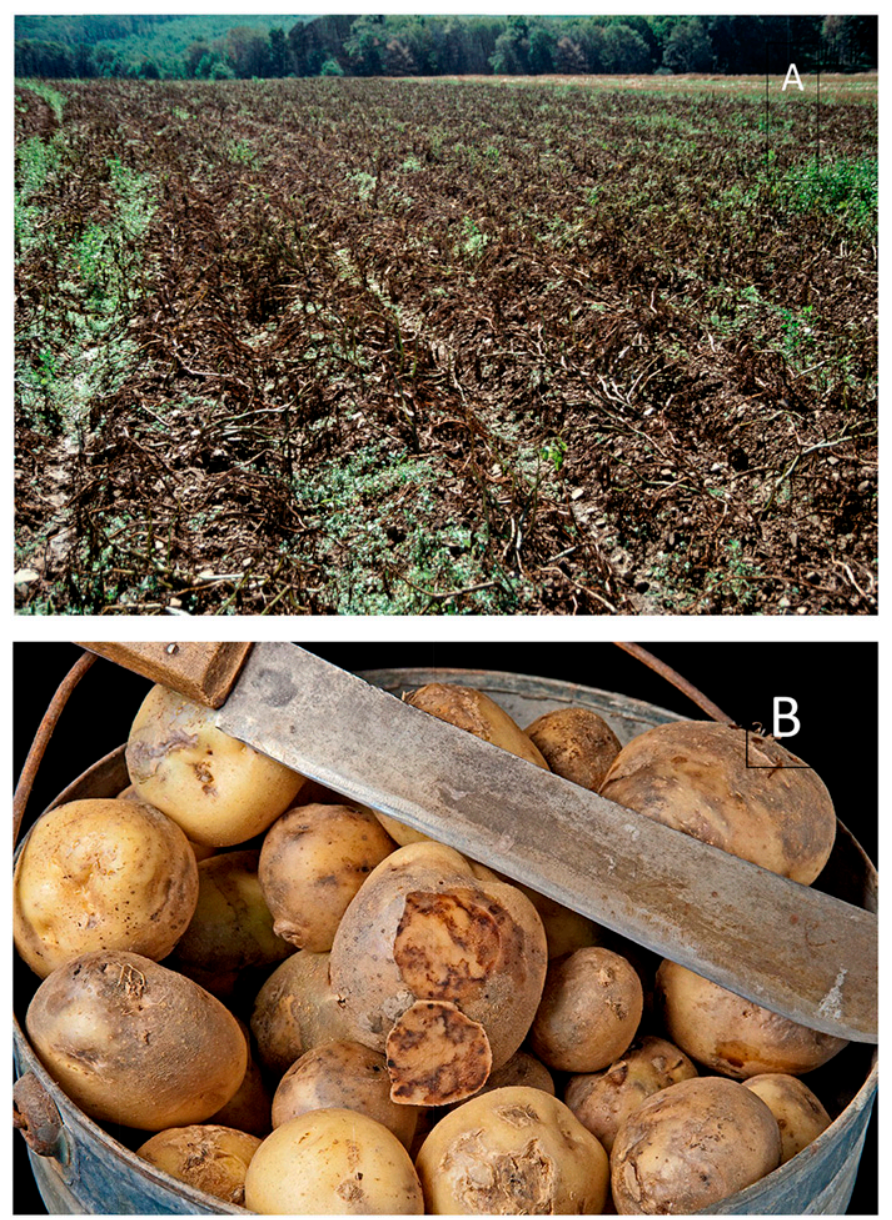

Fig. 1. Illustrations of devastation on potato caused by Phytophthora infestans. A, Field of potato in which all foliage has been destroyed by P. infestans. Only weeds are green. Repeated asexual cycles of reproduction lead to very rapid destruction of foliage. B, Potato tubers infected by P. infestans. Sporangia washed through the soil contact tubers and lead to infections.
Reddick was willing to suggest that Mexico was the center of origin of $P$. infestans (Reddick 1939).

The idea that central Mexico might be the center of origin for $P$. infestans gained much momentum when it was discovered in the 1950 s that the $P$. infestans population in the Toluca Valley in central Mexico was sexual, containing both A1 and A2 mating types (Galindo and Gallegly 1960; Gallegly and Galindo 1958; Niederhauser 1956). Prior to that time, P. infestans had been thought to be exclusively asexual (De Bary 1863; Reddick 1939). Demonstration that the population in central Mexico was very diverse genotypically (Grünwald and Flier 2005; Grünwald et al. 2001) further coalesced opinion that central Mexico was the center of origin of this species.

This hypothesis prevailed until the early 21 st century, when a study by Gomez-Alpizar et al. (2007) on mitochondrial and nuclear gene genealogies of isolates from several locations worldwide caused these authors to conclude that $P$. infestans had a South American origin. Their report refueled the controversy but a subsequent study (Goss et al. 2014), using a wider set of isolates and including more close relatives of $P$. infestans, again led to a conclusion that the highlands of central Mexico are the center of origin. This latter study reconciles previous observations about genetic diversity, host range, and the natural history of the pathogen.

Irish famine strain? We have also long been interested to know the identity of the specific strains of $P$. infestans that caused
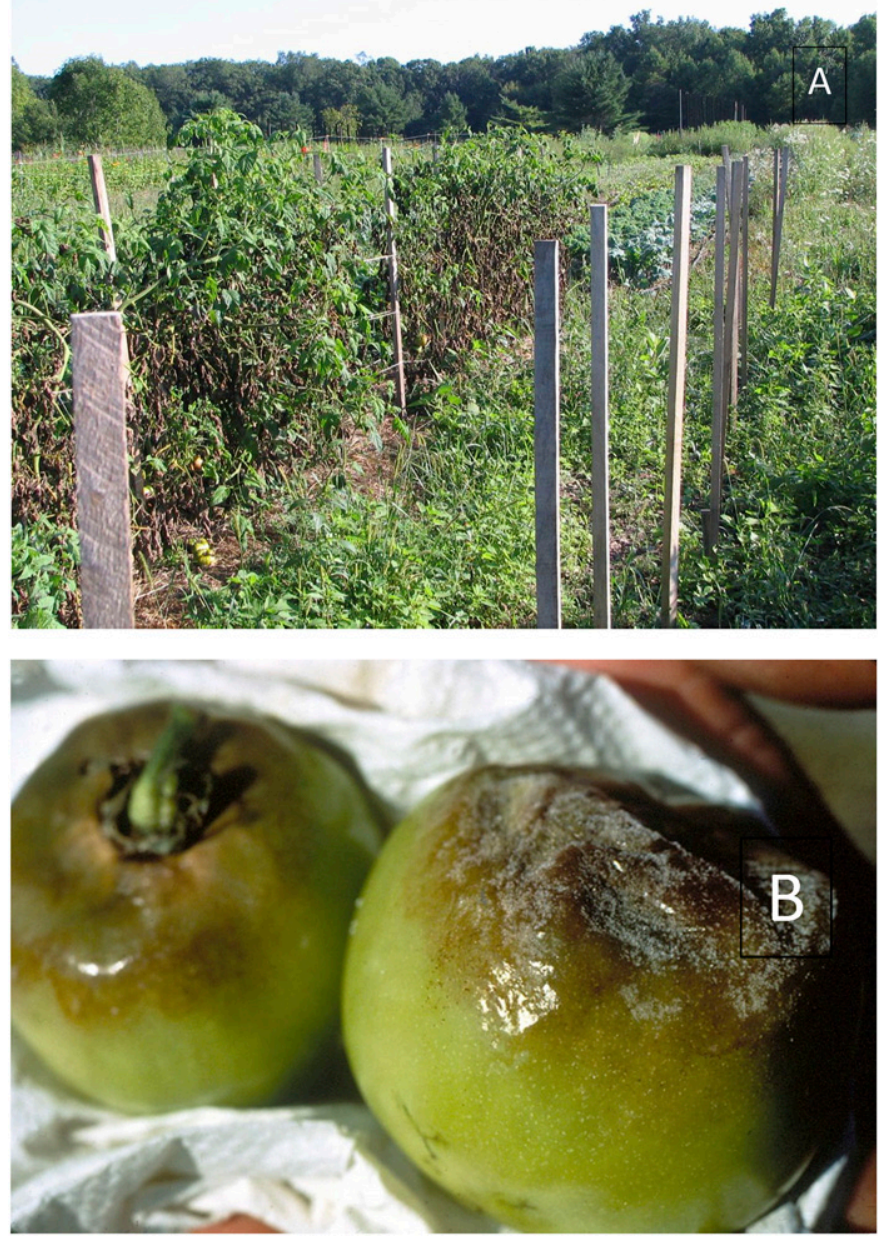

Fig. 2. Devastation of tomato by Phytophthora infestans. A, Tomato plants severely affected by late blight on a small farm. Most of the lower foliage had already been killed. This was the only planting of 10 different plantings of tomato on this particular farm that had not yet been totally destroyed. B, Tomato fruit infected by $P$. infestans (photo by T. A. Zitter). 
the Irish potato famine. Goodwin et al. (1994b) suggested that the famine might have been caused by the US1 clonal lineage of $P$. infestans. They based their suggestion on the worldwide dominance of this clonal lineage in the mid- to late 20th century (Goodwin et al. 1994b). However, analyses of herbarium specimens indicated that US1 was not present in 1845 (Ristaino et al. 2001). Further evidence on this topic was obtained by two groups of investigators who used shotgun sequencing of herbarium samples that had been collected between 1845 and 1896 and comparison of these to modern strains (Martin et al. 2013; Yoshida et al. 2013). This analysis confirmed that US1 was not present in 1845 but, instead, populations were dominated by a single genotype named HERB-1 (Yoshida et al. 2013). HERB-1 apparently dominated for 50 years but was subsequently replaced by the closely related US1 clone (Yoshida et al. 2013). As further evidence of the generality of interest in these historical questions, the name HERB-1 was even the subject of television comedy in the United States (http:// thecolbertreport.cc.com/videos/7fm2v2/irish-potato-famine-pathogen).

\section{SURPRISINGLY SEVERE EPIDEMICS}

Another reason that late blight seems to be continually emerging is that there have been repeated occurrences worldwide where the disease has become unexpectedly serious. These events are surprising because they are not explained by unusual weather. Instead, changes in the pathogen population are frequently associated with such situations. We describe here several such events.

United States and Canada. During the past four decades in the United States and Canada, late blight has been particularly
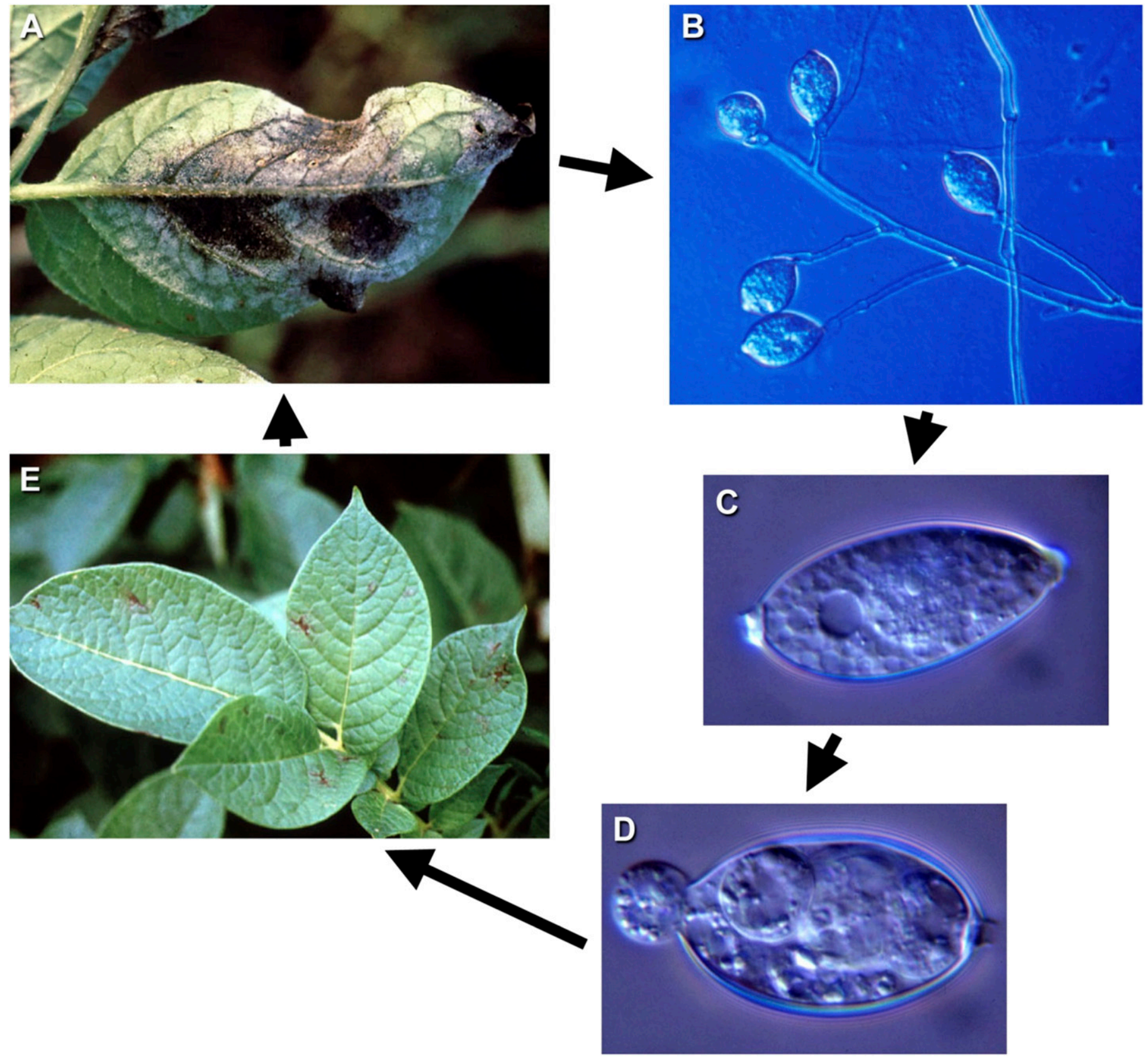

Fig. 3. Asexual life cycle of Phytophthora infestans on potato tissue. A, After moist conditions for several hours (at least 6 to $8 \mathrm{~h}$ ) at moderate temperatures (15 to $22^{\circ} \mathrm{C}$ ), the pathogen sporulates from lesions. B, Sporangia are borne on sporangiophores and $\mathbf{C}$, sporangia are dehiscent (readily removed from sporangiophores) and are aerially dispersed. D, Sporangia can germinate directly (via a germ tube at warmer temperatures $\left[>18^{\circ} \mathrm{C}\right]$ ) or at lower temperatures $\left(<18^{\circ} \mathrm{C}\right)$ via zoospores. E, Within 3 to 6 days, young lesions appear on after infection on host tissue. This image was first published by Fry (2008) and, subsequently, by Fry et al. (2013). 
severe twice over large regions-once in 1994 to 1995 (Fry and Goodwin 1997) and again in 2009 (Fry et al. 2013). In the early 1990s, exotic strains from Mexico (US6, US7, and US8) that were particularly aggressive and resistant to the fungicide metalaxyl (now known as mefenoxam) were introduced (Goodwin et al. 1994a). These strains caused severe epidemics throughout both the United States and Canada in 1994 and 1995 (Fry and Goodwin 1997). Losses quantified in the 1995 epidemic in the Columbia basin in the Pacific Northwest were estimated at \$30 million (Johnson et al. 1997). To manage these new strains, it was predicted that approximately $25 \%$ more fungicide applications would be required than for the previously dominant strains (Kato et al. 1997). Growers have indicated that this prediction was correct.

In 2009, a tomato late blight pandemic in the eastern United States unfortunately introduced many organic growers and home gardeners to the late blight disease (Fry et al. 2013; Hu et al. 2012). It seems likely (at least for the United States) that this epidemic introduced more non-plant pathologists to the disease and pathogen than any other single recent event. The emotional and economic effect on a home gardener is illustrated in the following e-mail to W. E. Fry:

\section{Date: Fri, 24 Jul 2009 18:03:47-0700}

FYI: I am an organic gardener in Amsterdam, NY with 63 heirloom tomato plants of 23 different varieties, all gone. I was growing very rare varieties, blacks, greens, oranges, whites. All purchased from a very reputable grower in Schoharie. Tonight I had to leave home as my husband is pulling and bagging all 63 plants. I have $100 \%$ loss. We live on ten acres. I inspected every day and it seems the blight took my plants in matter of hours. I was hoping to sell them for additional income.

During the 2009 pandemic, there were many articles in the popular press-and much digital communication. The interest was chronicled via "Google Trends" (Scherm et al. 2014). Based on these data, it's clear that there is an annual interest in the summer but this was greatly magnified in 2009 (Fig. 4).

In contrast to the majority of situations described below, the pandemic in 2009 was not caused by the introduction of particularly aggressive strains (Danies et al. 2013) or by particularly favorable weather (Fry et al. 2013). Instead, the pandemic was caused by the massive distribution of a particular strain (US22) via infected tomato transplants from a single national supplier sold in large retail stores over large regions of the United States (Fry et al. 2013).

The pandemic of 2009 stimulated an interest in generating more accurate data concerning populations of $P$. infestans in the United States on a near real-time basis. Fortunately, a United States Department of Agriculture, Agriculture and Food Research Initiative grant enabled such analyses. Microsatellite markers developed by Lees et al. (2006) were used to identify the clonal lineage of $P$. infestans in each sample that was submitted to a central laboratory for analysis. The specimens were sent via overnight courier and, in the vast majority of cases, the results were returned to the submitter within 1 or 2 days of receipt, and also reported on a national website (www.USAblight.org), which also contains a map illustrating the location (county). This information was valuable to the submitter because each clonal lineage had reasonably consistent and unique fungicide resistance and host preference characteristics, which could help growers develop their management plans (Table 1) (Danies et al. 2013).

A chronological description of the reports obtained from 2009 through 2014 is provided in Figure 5. Most reports came from the eastern part of the United States. Although there were certainly additional occurrences of late blight in the country, the samples submitted to the central lab resulted in the most extensive and comprehensive assessment of P. infestans in the United States in history. Summaries of these reports were recorded on USAblight.org.

There were just a few dominant clonal lineages in the United States during 2009 to 2014 (Fig. 6). This is consistent with the situation for the previous decade as well - a small number of clonal lineages dominated the population of $P$. infestans (Fig. 6) in any particular year.

A feature of $P$. infestans in the United States has been that the population structure is typically very simple, often with only a single lineage in a region (Fig. 5), or with only a single lineage on potato and sometimes a different lineage on tomato (Fig. 7). For example, in 2009, only US8 and US22 were widely reported (Fig. $6)$. US22 was reported on potato and tomato but US8 was reported only on potato (Fig. 7). US23 and US24 were reported in 2009 but at low frequency (Hu et al. 2012) (Fig. 5). US11 was very important in Florida in 2012 (Figs. 5 and 6). Interestingly, there has been some regional substructuring, with US11 and US24 being the most common in the western United States (Fig. 5). Since 2011, US23 has become increasingly dominant (Figs. 6 and 7) and has been the only lineage reported in many states in 2012, 2013, and 2014 (Fig. 5). US23 has recently expanded its range westward (Fig. 5).

The simplicity of the population structure has been useful to the management of late blight in the United States. This is because the phenotype of most individuals within a lineage is relatively conserved. Characterizing the phenotype of an isolate can require

TABLE 1. Phenotypic characteristics of the most common clonal lineages detected in the United States in 2009 to $2014^{\mathrm{a}}$

\begin{tabular}{lcll}
\hline Lineage & A1 or A2 & Host preference & \multicolumn{1}{c}{ Mefenoxam sensitivity } \\
\hline US8 & A2 & Potato & Moderately resistant \\
US11 & A1 & Potato and tomato & Resistant \\
US22 & A2 & Potato and tomato & Sensitive \\
US23 & A1 & Potato and tomato & Sensitive to moderately sensitive \\
US24 & A1 & Potato & Moderately sensitive \\
\hline
\end{tabular}

a Data are from Childers et al. (2015), Danies et al. (2013), and Hu et al. (2012).

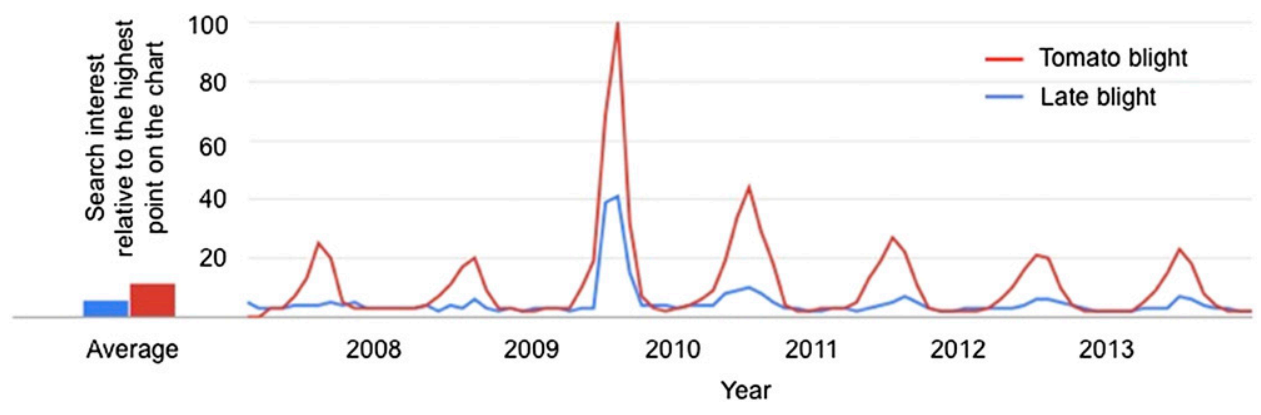

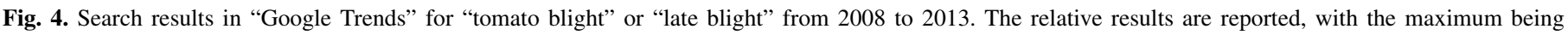

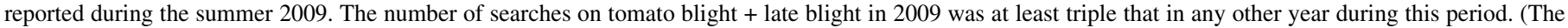
absolute number of searches was not discernable from the website.) 
weeks to months - particularly if one needs to work with the isolate in pure culture. However, determining the genotype of the pathogen from a sporulating lesion using simple-sequence repeats (SSRs, or microsatellites) can be done in less than $24 \mathrm{~h}$. Thus, from knowledge of the phenotype of individuals in a lineage, one can typically predict the impact of certain management actions. For example if tomato growers are aware of potato late blight in the area, and if they also know that the lineage causing potato late blight is US8 or US24, then they can safely conclude that their tomato crop is not at immediate risk. In contrast, if the lineage on potato is US23, they need to take immediate precautions, because US23 is very aggressive on tomato. Growers would also know that mefenoxam could be used to help protect their tomato crop because US23 has been largely sensitive to mefenoxam in the United States. Finally, if US11 was on potato, then immediate action would be necessary because US11 has been consistently highly pathogenic to both tomato and potato and resistant to mefenoxam (Saville et al. in press). Of course, it is necessary to continually monitor the
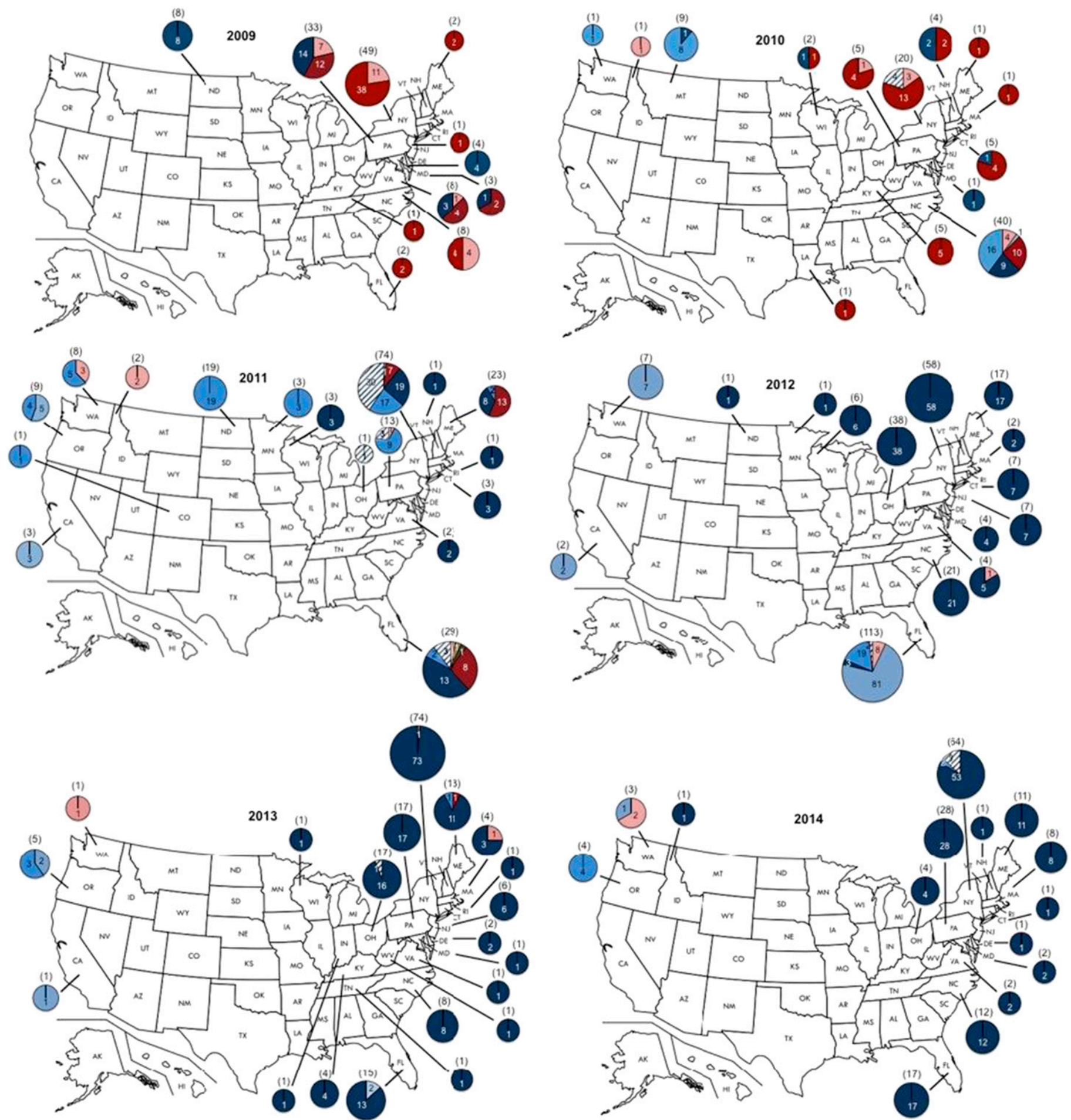

Fig. 5. Reports of diverse genotypes of Phytophthora infestans by state from 2009 through 2014 . The genotype is indicated by the color scheme identified in Figure 6. The number of the samples from a state is identified in the circle and the size of the circle reflects the number of samples reported. In many states in 2012, 2013, and 2014, only US23 was reported. 
phenotypes of diverse strains to learn whether mutants with new epidemiologically important traits have appeared.

Southwest India. In southwest India (Karnataka state, with 46,000 ha of tomato for fresh market), late blight of tomato had not been reported as a particularly important disease prior to 2007, even though the disease had been reported there on potato since 1953 (Chowdappa et al. 2013). However, in 2009 and 2010, there were severe tomato late blight epidemics, with crop losses of up to $100 \%$ (Chowdappa et al. 2013). The genotypes of 19 isolates obtained from diseased tomato plants in different locations in Karnataka were assayed using molecular markers (SSR and RG57). All assays were consistent with these isolates being members of the 13_A2 genotype (Blue_13) of P. infestans (Chowdappa et al. 2013)-the particularly aggressive genotype that dominated Great Britain in 2005 to 2008 (Cooke et al. 2012). It seems likely that migration of 13_A2 into India was responsible for the increased disease severity. Mechanisms for such migration events exist. There were importations of tons of seed potato from Great Britain and Europe prior to 2009 (Chowdappa et al. 2013), where this lineage had been dominant. Subsequent collections revealed that 13_A2 was also detected on potato in 2010, 2011, and 2012 (Chowdappa et al. 2015). Because 13_A2 is pathogenic on tomato as well as on potato, and because it is more aggressive than the previously dominant strains, there has been a dramatic five- to sevenfold increase in the number of fungicide sprays applied to tomato in Karnataka (Chowdappa et al. 2013). Late blight is certainly a reemerging disease in Karnataka, India.

Tunisia. A North African example of unexpected late blight severity occurred in Tunisia in the first decade of the 21 st century (Harbaoui et al. 2014). This was coincident with the first report of an A2 mating type isolate in Tunisia (Harbaoui et al. 2014), which raised the possibility that there have been changes to the $P$. infestans population there. One clonal lineage (North Africa 01 [NA-01]) was dominant, particularly on tomato (Harbaoui et al. 2014). However, a group of diverse strains (containing both A1 and A2 mating types) was found in a region in which late blight was particularly difficult to manage. It is not yet determined whether or not there is a residential sexual population of $P$. infestans in Tunisia (Harbaoui et al. 2014). In contrast to the situation in southwest India, the diverse isolates on potato in Tunisia appear unrelated to current European strains (Harbaoui et al. 2014).
Other locations. In addition to unexpected occurrences of severe late blight in the United States and Canada, India, and Tunisia, we are aware of similar events in Chile, China, Oman, and Nigeria. In Chile, late blight was first reported in the 1950s but it has become very serious since 2005 (Acuna et al. 2012). Before 2005, the mitochondrial haplotype was Ib (Acuna et al. 2012) suggestive of the US1 clonal lineage. However, the current population is characterized by the Ia mitochondrial haplotype and is resistant to mefenoxam (Acuna et al. 2012). This population retains a strongly clonal structure, with only A1 mating types being reported (Acuna et al. 2012). China leads the world in potato production ( $\mathrm{Li}$ et al. 2013). Prior to 1996, only A1 mating type strains had been reported (Li et al. 2013). Strains of the A2 mating type were first detected in 1996 (Zhang et al. 1996). A dominant clonal lineage (SIB-1) was found widely throughout China and was identical to that lineage found in Siberia, suggesting migration between Russia and China (Guo et al. 2010). Interestingly, the 13_A2 lineage is now well established in China in the Sichuan province, having been detected as early as 2007 (Li et al. 2013). Some variants of the lineage were also detected in Sichuan (Li et al. 2013) but, as of 2013, there was not yet evidence for a residential sexual population. (Li et al. 2013). Very recent reports (2012 and 2013) of unexpectedly severe late blight in Oman (A. O. Al-Adawi, personal communication) and Nigeria (R. Bandyopadhyay, personal communication) are, thus far, observational and populations there have not yet been characterized. It is logical to conclude that the total number of unexpected occurrences is unknown but, in each of the locations above, late blight is indeed reemerging.

\section{CHANGES IN POPULATIONS OF P. INFESTANS WORLDWIDE}

For the first century or more of its existence in Europe, the United States and Canada, Africa, and Asia, populations of P. infestans appear to have been highly clonal, with domination first by HERB-1 (Yoshida et al. 2013), and later by US1 (Goodwin et al. 1994b), although HERB-1 might be part of a larger US1 metapopulation. US1 is of the A1 mating type. The mating type of HERB-1 is not known but we hypothesize that it was also A1, because the occurrence of two A1 mating types explains the absence until the mid-20th century of documented sexual reproduction of
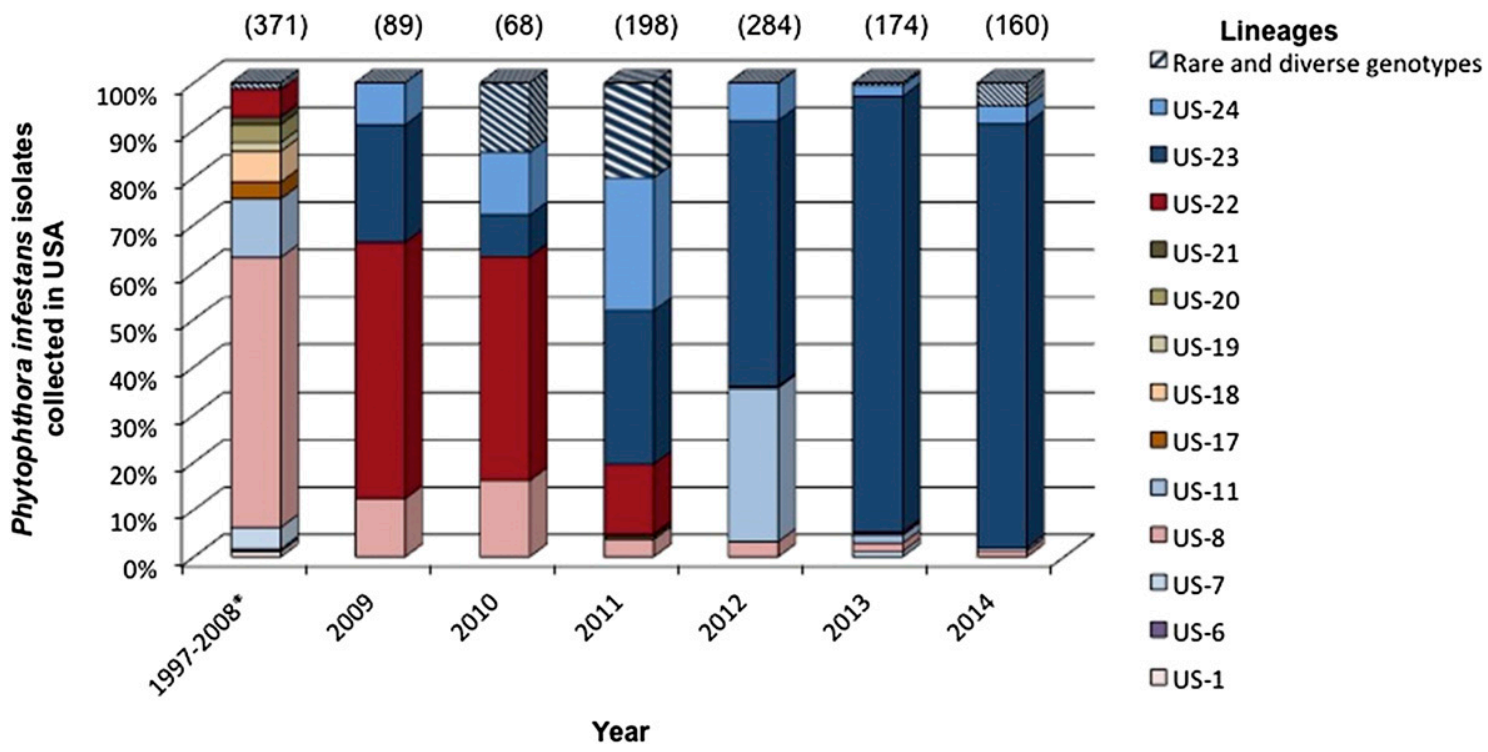

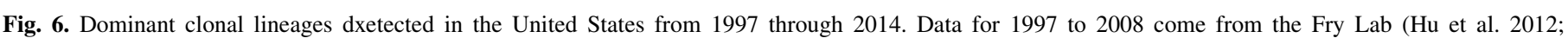

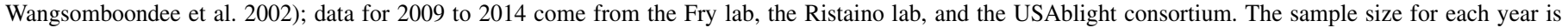
indicated in parentheses at the top of each column. 
P. infestans. Obviously, the situation in central Mexico was entirely different, with a very diverse and sexual population (Grünwald and Flier 2005).

The absence of sexual reproduction in most parts of the world meant that $P$. infestans was essentially an obligate parasite (requiring a living host for its long-term survival) everywhere except in central Mexico. In potato agroecosystems in the temperate zone, infected tubers from storage or from the field (as volunteers) provide a mechanism for survival between seasons. In the absence of living host tissue and as an asexual organism, survival is much shorter. Sporangia can survive for weeks in soil (Mayton 2006). In contrast, oospores can survive for years in soil (Drenth et al. 1995; Mayton et al. 2000), and they can also survive drying while in soil (Fernandez-Pavia et al. 2004).

Thus, the presence or absence of sexual recombination is a huge factor in the epidemiology of late blight. Additionally, sexual reproduction generates new genotypes of the pathogen with unexpected traits. Finally, there was the fear that a soil source of the pathogen might lead to more common and earlier epidemics. It is for these several reasons that most countries did not allow imports of potato from central Mexico. Any introduction of A2 mating type strains had been highly feared.
Thus, the first report of A2 mating type strains outside of Mexico in Switzerland in 1984 (Hohl and Iselin 1984) was enormous news. This first report stimulated other investigators to search locally for A2 mating type strains, and these searches detected some A2 strains, first in Europe (Shaw et al. 1985), then in the United States and Canada (Deahl et al. 1991), and subsequently in Asia (Nishimura et al. 1999; Singh et al. 1994; Zhang et al. 1996).

In Europe, the detection of A2 strains in the 1980s was the initial indication of a major migration event and subsequent population shift. The US1 strain that had dominated non-Mexican populations worldwide prior to the 1980s was displaced by a diverse population containing both A1 and A2 strains (Fry and Goodwin 1997; Spielman et al. 1991). These exotic strains were quickly associated with more severe late blight outbreaks (Leary 1993).

A major concern was that sexual populations would occur in locations where these new strains now were dominant. Certainly there was considerable diversity present in such populations in northern Europe. There were reports of diverse populations in the Netherlands (Fry et al. 1991; Zwankhuizen et al. 2000), Poland (Sujkowski et al. 1994), Estonia (Runno-Paurson et al. 2009), and the Nordic countries (Lehtinen et al. 2008). In these locations, both A 2 and A1 mating type individuals were present —often in the same

A

A

(49)

(41)

(89)

(197)

(114)

(108)

Lineages

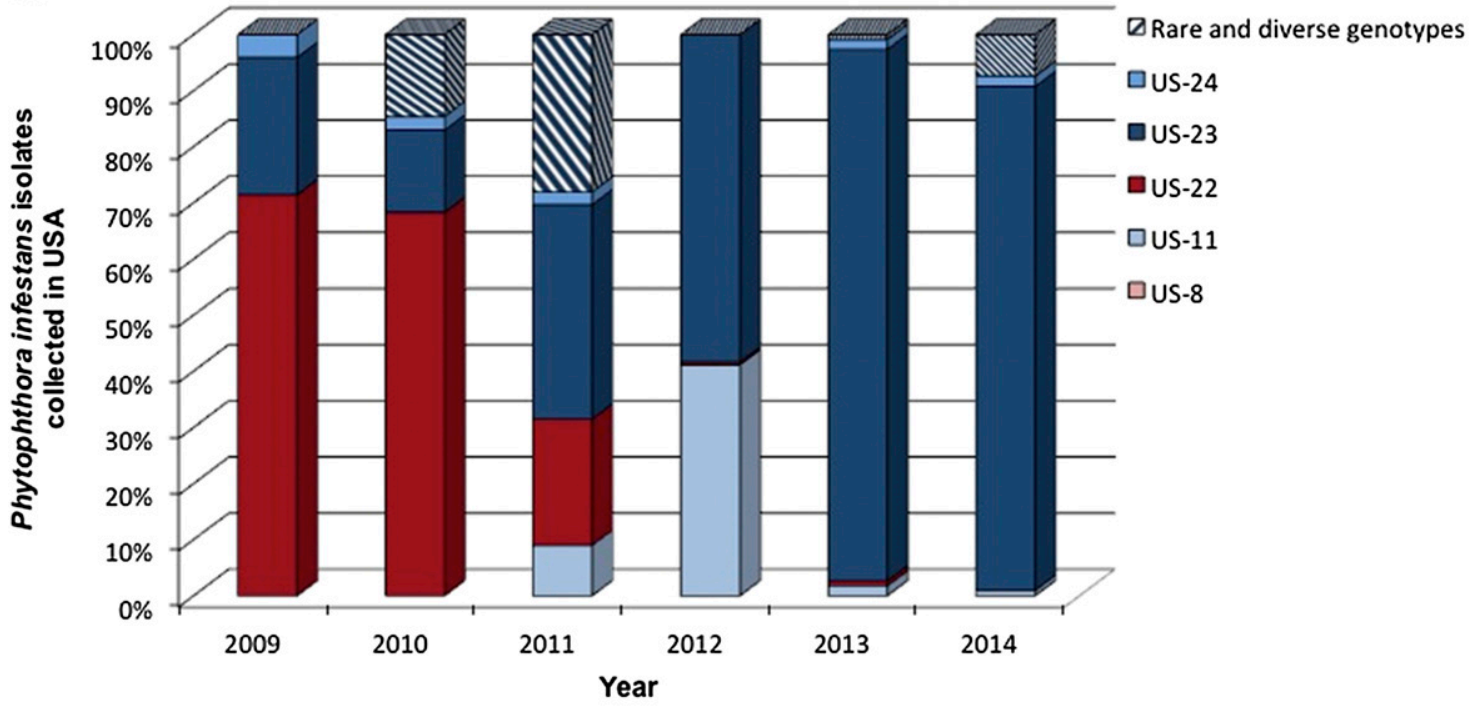

B

(40)

(27)

(76)

(73)

(50)

(61)

$\checkmark$ Rare and diverse genotypes

口US-24

aUS-23

घUS-22

口US-11

口US-8

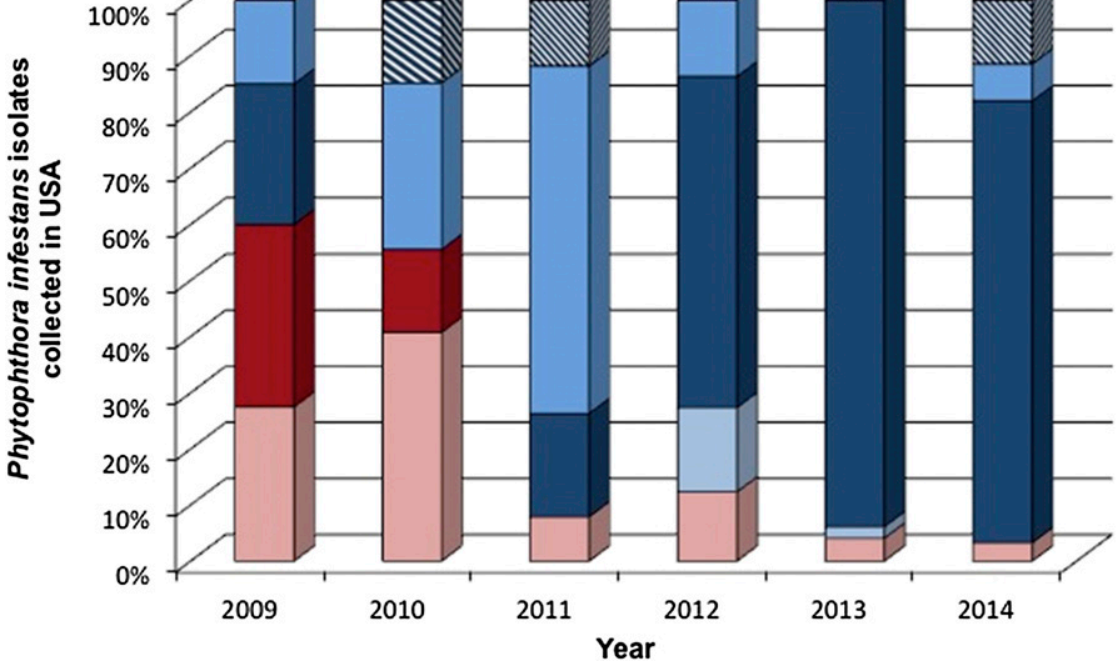

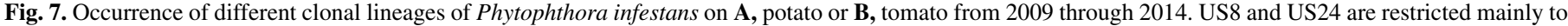
potato. Data for 2009 to 2014 come from the Fry lab, the Ristaino lab, and the USAblight consortium. 
field in high proportion. Fortunately, the mere occurrence of both A1 and A2 strains in a region is not alone sufficient to create a residential sexual population. For example, both A1 and A2 strains have been in the United States for over 20 years but a residential sexual population has not been detected (see below).

In northern Europe, there is now convincing evidence that there are residential sexual populations of $P$. infestans, particularly in the Nordic countries (Yuen and Andersson 2013). One of the first indications occurred in a field experiment conducted in Sweden in 1996 (Andersson et al. 1998). In that experiment, late blight was associated with particular locations in the field where late blight in 1994 had been severe (Andersson et al. 1998). Cereals were planted in 1995 and there had been no potato in the field in 1995 (Andersson et al. 1998). Both mating types were detected among isolates obtained from that field in 1996 and oospores were observed in infected tissue (Andersson et al. 1998). Unfortunately, the reported genetic diversity in that research field turned out to be a predictor of a now common situation in the Nordic countries (Brurberg et al. 2011): very high genetic diversity among $P$. infestans isolates. In a study involving 200 isolates from Denmark, Finland, Norway, and Sweden, $75 \%$ of individuals were unique, as determined by analysis using only nine SSR loci (Brurberg et al. 2011).

The epidemiological consequences of a residential sexual population have been reported by Hannukkala et al. (2007). These authors studied late blight epidemics in Finland from 1933 to 1962 and from 1983 to 2002. They found that the risk of a late blight outbreak was 17-fold greater in 1998 to 2002 than in two previous periods (1933 to 1962 and 1983 to 1997) and occurred 2 to 4 weeks earlier than before (Fig. 8) (Hannukkala et al. 2007). Weather probably contributed in only a minor way to the increased intensity of late blight because the number of rainy days had increased only slightly (Hannukkala et al. 2007). Interestingly, once epidemics started, they did not differ in intensity from those in the earlier period. Nonetheless, the earlier start to epidemics caused Finnish farmers to apply fungicides more frequently_almost doubling the number of annual applications from the early 1990s to the period 1997 to 2002 (Fig. 9) (Hannukkala et al. 2007).
It seems clear that the fears of plant pathologists concerning the introduction of a diverse population containing individuals with both mating types were well founded. The evidence clearly leads to the conclusion that, in the Nordic countries and probably also in other parts of northern Europe, the introduction of a diverse population has established residential sexual populations in agricultural fields. The newly formed residential sexual populations are responsible for generating high genetic diversity in the pathogen population. The soil has become a source of inoculum and epidemics are now starting earlier.

Fortunately, in other parts of the world, recent studies have detected populations that are largely clonal with no evidence for sexual reproduction. For example, Montarry et al. (2010) found two admixed clonal populations of $P$. infestans in 220 isolates collected from 20 commercial fields in 2004 and 2005 in France. They concluded that this population structure resulted from limited or no sexual reproduction in the French $P$. infestans population (Montarry et al. 2010). In China and India, recent populations were strongly clonal, with no strong evidence for sexual reproduction (Chowdappa et al. 2013, 2015; Li et al. 2013).

In the United States and Canada, reported populations of $P$. infestans remain strongly clonal, with little evidence of residential sexual populations that contribute significantly to the ecology and epidemiology of this pathogen (Fry et al. 2013; Hu et al. 2012). However, there are two reports of ephemeral populations that were apparently recombinants. These populations are ephemeral because, after the initial detection, there has not been further production of recombinant individuals and most strains were not detected subsequently - probably because most of the recombinants were not as fit as the dominant genotypes. The first such population was detected in the Columbia basin of the Pacific Northwest in 1993 (Gavino et al. 2000). The diversity characterizing these isolates was dramatically different from collections from other parts of the United States in the 1980s, 1990s, and the 2000s. The population contained both mating types and many combinations of alleles in isolates collected in rather close geographical proximity (Gavino et al. 2000). The authors postulated that the parents of this

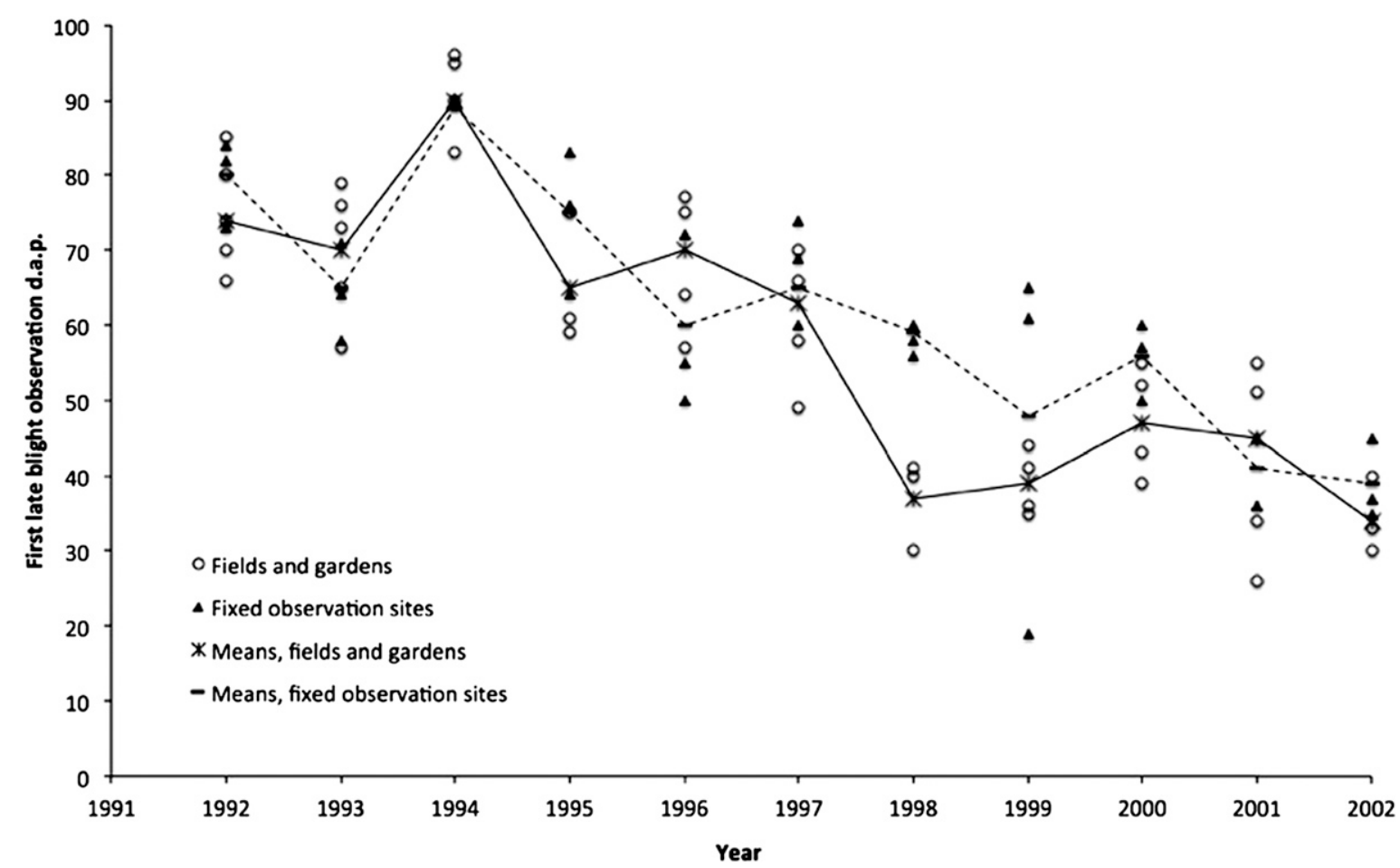

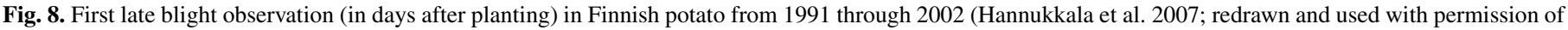
the author and publisher). 
population were US6 and US7, and that one of the progeny was US11 (Gavino et al. 2000), a lineage that has been very troublesome for more than 20 years. However, other progeny of this recombination event have not been detected for many years, so that most of the progeny appeared only ephemerally. Nonetheless, this progeny provides an example that recombination can produce individuals that are particularly troublesome.

The second ephemeral recombinant population has been reported recently from the northeastern part of the United States (Danies et al. 2014). The majority of isolates were detected in central or western New York State. These isolates were detected in 2010 and 2011 but not subsequently. As in the Pacific Northwest in 1993, this population contained diverse individuals in a somewhat localized region and had great diversity for allele combinations based on analysis of allozymes, mating type, restriction fragment length polymorphism (RFLPs), and microsatellites (Danies et al. 2014). The parents for this population were postulated to be US22 (A2) and at least two other genotypes. Using a recent protocol that identifies at least 36 mitochondrial haplotypes, these individuals all had the same mitochondrial haplotype (H-20), the same haplotype as US22 (Danies et al. 2014). As with the 1993 population, this 2010-11 population appears to have been ephemeral, because these individuals have not been detected since 2011 (Danies et al. 2014). However, these two reports of recombinant progeny in the United States demonstrate that sexual reproduction is possible and may happen again.

\section{CONTRIBUTIONS OF GENOMICS TO ENHANCING OUR UNDERSTANDING OF HOST-PATHOGEN INTERACTIONS}

Evolution from "nightmare" to model. A key challenge to the scientific community in trying to combat late blight can be encapsulated by the phrase 'know your enemy'. Over more than a decade late blight researchers have embraced the genomics era, providing a molecular framework within which to tease out the details of infection processes. The subsequent progress has caused $P$. infestans to be considered as the most important oomycete in molecular plant pathology (Kamoun et al. 2014). How does $P$. infestans evade, manipulate, or overcome the immune system of major crop hosts such as potato and tomato? Why have so many efforts to breed for resistance been dismissed with apparent disdain by this pathogen? The legendary capacity for $P$. infestans to adapt to environmental diversity or overcome almost all obstacles that breeders have laid before it has created a "nightmare" disease that cannot be stopped except through the copious application of agrochemicals. The genomics era is starting to provide insight into the mechanisms and processes underlying $P$. infestans pathogenicity. With such understanding, our ideas about how to prevent late blight are becoming more sophisticated.

Large-scale studies of expressed sequence tags (Kamoun et al. 1999; Randall et al. 2005) followed by the genome sequence (Haas et al. 2009) have provided the entire genetic blueprint with which to discover the molecular components of $P$. infestans pathogenicity. These resources have been combined with bioinformatic algorithms to predict genes encoding proteins with secretion signal peptides (Torto et al. 2003). This has revealed many candidate proteins that are exported from the pathogen and which, thus, may directly interact with plant cells. Among the central players that dictate whether microbial infection results in plant disease or disease resistance are effector proteins. Effectors may act outside of plant cells (so-called apoplastic effectors) or be delivered to the inside of living plant cells (cytoplasmic effectors) to suppress immunity and alter host processes in favor of the invading microbe. In contrast, effectors are themselves "targets" for recognition by host resistance proteins and their detection activates the hypersensitive response, including programmed cell death (PCD), a process more recently referred to as effector-triggered immunity (ETI) (Jones and Dangl 2006).

Apoplastic $P$. infestans effectors include a number of inhibitors of secreted, defense-associated host enzymes. Inhibitors of either cysteine (Tian et al. 2007) or serine (Tian et al. 2004) proteases and of secreted glucanases (Damasceno et al. 2008) have been characterized. The effectors are exquisitely specific to the host enzymes that they target. The cysteine protease inhibitor EPIC1 targets the tomato protease RCR3, which is also a target of fungal Passalora fulva (Cladosporium fulvum) effector CfAVR2 (Song et al. 2009), and of the nematode effector Gr-VAP1 (Lozano-Torres et al. 2012), indicating that pathogens from diverse kingdoms need to disable the same host proteins to undermine plant immunity. Interestingly, perturbations to RCR 3 by CfAVR 2 and Gr-VAP1 are detected by the tomato resistance protein Cf2 (Lozano-Torres et al. 2012), revealing that monitoring, or guarding, host proteins can provide resistance to multiple pathogens. Recently, diversifying selection of the EPIC1 protease inhibitor orthologs from Phytophthora infestans and the closely related $P$. mirabilis was shown to be required for inhibition of the equivalent protease targets within their respective hosts, tomato and Mirabilis jalapa (Dong et al. 2014).

Cytoplasmic effectors from $P$. infestans include the RXLR class, named for the conserved Arg-any amino acid-Leu-Arg motif that is required for their translocation inside plant cells (Whisson et al. 2007), and the crinkler candidate effector class, which has been shown to be translocated inside living plant cells (Schornak et al. 2010). All $P$. infestans avirulence proteins detected by cytoplasmic nucleotide-binding leucine-rich repeat resistance $(\mathrm{R})$ proteins are

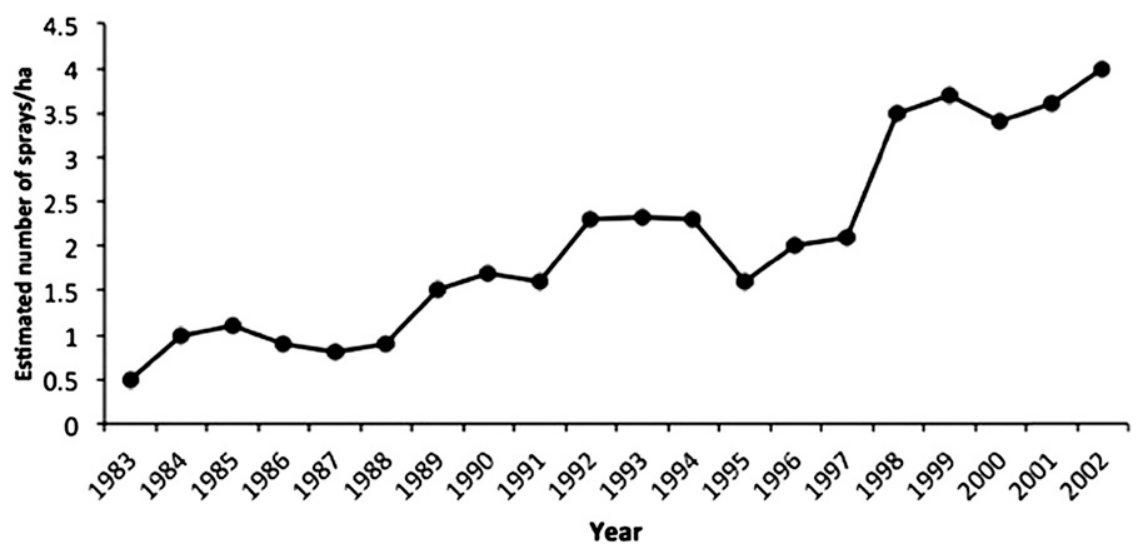

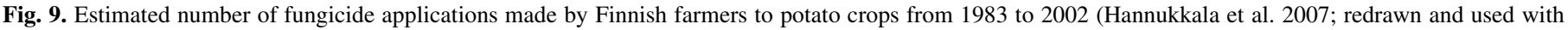
permission of the author and publisher). 
members of this class of effectors (Rodewald and Trognitz 2013; Vleeshouwers et al. 2011). Our understanding of what P. infestans RXLR effectors target in host plant cells, and how they act collectively to promote pathogenicity, is in its infancy. Nevertheless, each effector can be regarded as an experimental "probe" to explore host regulatory and mechanistic processes that are disabled or altered to cause disease. The RXLR effector PiAVR3a stabilizes the host ubiquitin E3 ligase CMPG1 to prevent PCD triggered by perception of elicitors such as the secreted elicitin INF1 (Bos et al. 2010). PiAVR-blb2 has been shown to prevent secretion of defenseassociated proteases (Bozkurt et al. 2011). PiAVR2 interacts with BSL1, a putative phosphatase implicated in brassinosteroid signal transduction. It is not known why BSL1 is apparently targeted but this interaction is detected by the resistance protein $\mathrm{R} 2$, resulting in ETI (Saunders et al. 2012). The RXLR effector Pi03192 prevents relocalization of two host NAC transcription factors from the endoplasmic reticulum to the nucleus, thus presumably attenuating their normal activity (McLellan et al. 2013). More recently, PexRD2 has been shown to interact with and inhibit mitogen-activated protein (MAP) $3 \mathrm{~K} \varepsilon$, which is required for signal transduction leading to PCD following activation of the immune receptor $\mathrm{Cf} 4$ (King et al. 2014). In addition, a range of $P$. infestans RXLRs act redundantly to suppress the activation of a different MAP kinase pathway and subsequent host early gene expression following perception of the elicitor flg22 by receptor FLS2 (Zheng et al. 2014). Given that potentially hundreds of RXLR effectors are encoded by the $P$. infestans genome (Haas et al. 2009), many more effector targets and alternative modes of action to manipulate host immunity are likely to emerge in the coming years. However, our preliminary studies, driven initially by genomics, provide a model of a sophisticated pathogen with effectors acting inside or outside of host cells to disable or manipulate many host processes for its benefit.

The use of effectoromics in the search for durable disease resistance. Breeding for late blight disease resistance has a long history with little sustained success. Cycles of "boom and bust: are well documented because dominant $R$ genes, introgressed through lengthy programs of breeding, have been deployed only to be overcome within a few growing seasons by virulent genotypes emerging from rapidly changing pathogen populations. This has led to $P$. infestans being described as the plant and $R$ gene destroyer (Fry 2008 ). To get a grip on how the pathogen overcomes these $R$ genes, it is important to identify the avirulence (AVR) effectors that they recognize.

A number of $P$. infestans AVR genes have been identified, all of which encode RXLR effectors. They include AVR3a (Armstrong et al. 2005) AVR4 (van Poppel et al. 2008), AVR-blbl (Champouret et al. 2009; Vleeshouwers et al. 2008), AVR-blb2 (Oh et al. 2009), and AVR2 (Gilroy et al. 2011). Multiple mechanisms have been revealed by which $P$. infestans has evaded recognition by the corresponding $\mathrm{R}$ proteins. AVR4 can simply be lost from the pathogen effector repertoire; isolates that are virulent on $\mathrm{R} 4$ potato plants contain truncated or mutated, nonfunctional copies of $A V R 4$ (van Poppel et al. 2008, 2009). This indicates that not all effectors are required by the pathogen for infection. One way in which $P$. infestans may be able to readily lose an effector is if others perform a similar role. Functional redundancy has been shown recently; a number of effectors are able to block FLS2-mediated MAP kinase signaling in tomato, suggesting that loss of any one of these effectors can be compensated for (Zheng et al. 2014). Loss of an effector or silencing of its expression is implicated in evasion of detection by the potato $R 2$ gene (Gilroy et al. 2011). Nevertheless, virulent isolates possess a related effector, AVR2-like (A2L), containing amino acid polymorphisms that evade recognition by R2 but presumably retain pathogenicity function similar to AVR2 (Gilroy et al. 2011; Saunders et al. 2012). In addition to loss of an effector to evade recognition, it has been proposed that additional effectors may evolve to suppress the recognition of an avirulence protein. It has been reported that the effector variant IpiO4 is able to suppress recognition of AvrBlbl (ipiO1) (Halterman et al. 2010).

The genome sequence of $P$. infestans contains potentially $>500$ RXLR genes, many of which fall into families of related sequences (Haas et al. 2009). Some of the effectors within each family perhaps have similar functions. RXLR genes generally occupy repeat-rich, gene-sparse regions of the genome; locations at which higher rates of mutation and, possibly, transcriptional silencing may occur in order to reduce or control the expression of transposable elements which reside with the effectors (Haas et al. 2009). Indeed, small RNAs associated with silencing of RXLR effector genes have been observed in $P$. infestans following deep sequencing of sRNAs from isolates that differ in pathogenicity (Vetukuri et al. 2012). Thus, the genome sequence has revealed a high potential for evolutionary adaptation. Effector genes, in particular, can be readily duplicated and mutated, and copies can be silenced without compromising the overall infection efficiency of the pathogen. This further emphasizes the nightmare of controlling $P$. infestans, and explains why this pathogen is regarded as constantly reemerging as a threat to food security.

However, genomic and transcriptomic studies of $P$. infestans are also providing potential solutions. The transcriptome of the genotype 13_A2 (also known as Blue_13), an aggressive genotype that has emerged as the predominant form of $P$. infestans in Europe in the past decade, revealed that the expression of 45 RXLR effectors was conserved with two other genotypes tested (Cooke et al. 2012). This raises the possibility that some effectors may be essential for potato infection and, thus, cannot be readily lost to evade detection. The 13_A2 genome lacks functional copies of $A V R 1$ and AVR4 and possesses AVR2-like rather than AVR2, explaining why the corresponding $\mathrm{R} 1, \mathrm{R} 4$, and $\mathrm{R} 2$ resistances are overcome by this genotype. However, it expresses AVR-blbl, AVRblb2, and $A V R$-vnt1, and all three of the resistances Blb1, Blb2, and Vnt1 provide effective resistance to 13_A2 (Cooke et al. 2012). Therefore, genome-wide knowledge of the effectors that are expressed in different $P$. infestans genotypes may highlight a core set of key effectors for which corresponding resistances may be durable.

There is one additional consideration in prioritizing effectors as "good" targets for potentially durable $R$ genes: whether those effectors are essential for infection. AVR3a is a good example. Two alleles of $A V R 3 a$ have been reported within pathogen populations worldwide. They encode proteins differing in two amino acids (K80E and I103M); AVR3aKI is recognized by R3a, whereas AVR3aEM evades detection (Armstrong et al. 2005). Interestingly, historic lineages of $P$. infestans lack the virulent form of Avr $3 a$ and several other effectors, suggesting that modern plant breeding may have driven expansion of effectors in the pathogen (Martin et al. 2013). The genotype 13_A2 overcomes R3a because it only possesses AVR3aEM (Cooke et al. 2012). AVR3a is an essential pathogenicity determinant (Bos et al. 2010); therefore, deployment of an $R$ gene that targets AVR $3 \mathrm{aEM}$, in combination with $R 3 a$ itself, could impose strong selection pressure on the pathogen population.

Many programs to breed for late blight resistance have thus been reshaped by our knowledge of the $P$. infestans genome. An understanding of which RXLRs are universally expressed, which are essential for infection and whether they can be mutated to evade recognition while retaining their function, is focusing searches for specific $R$ genes that may provide durability (Birch et al. 2008; Vleeshouwers et al. 2008). Studies of effector diversity and function, and transient expression screens of key effectors within wild potato germplasm to seek corresponding $R$ genes, has now been termed "effectoromics" (Vleeshouwers and Oliver 2014; Vleeshouwers et al. 2011). The principles of effectoromics, applied initially to late blight, are being adopted for many other crop diseases.

Effectoromics has revolutionized our search for durable disease resistance, positioning our understanding of effector function, 
expression, and sequence diversity as central to finding $R$ genes with the potential to stand the test of time. Nevertheless, given the phenomenal capacity for $P$. infestans to evolve, it is likely that many such $R$ genes would need to be combined to provide a durable barrier to infection (Vleeshouwers and Oliver 2014). However, such durable barriers do exist in nature. Within the Solanaceae family, whereas $P$. infestans infects potato, tomato, and eggplant, it is not reported to infect pepper or tobacco. Recently, $P$. infestans effectoromics was applied to pepper in order to determine whether this nonhost crop could provide a new source of $R$ genes (Lee et al. 2014). Recognition of multiple $P$. infestans RXLR effectors was revealed, suggesting that pepper has already "stacked" $R$ genes to provide a durable barrier to late blight disease.

In addition to $R$ genes that recognize effectors, nonhost resistance may also be achieved by evolution of the targets of effectors, so that they may no longer either physically interact with an RXLR or be appropriately inhibited or manipulated by it. The recent studies by Dong et al. (2014) and Zheng et al. (2014) support this. As stated above, Dong and coworkers (2014) showed that orthologs of the secreted protease inhibitor EPIC1 from $P$. infestans and $P$. mirabilis possessed amino acid differences that tailored them to their job in their respective host plants. In addition, Zheng et al. (2014) showed that many of the P. infestans effectors that suppress early immune responses in the host plant tomato are unable to do the same in the nonhost plant Arabidopsis. The big question for the future is whether we can move effector targets from nonhost plants into host plants to see if they still function to promote immunity, while no longer being disabled by $P$. infestans effectors. The most durable barrier to late blight infection would be to convert potato and tomato into nonhost plants.

\section{COMPELLING UNANSWERED QUESTIONS}

What are the relationships among strains of $\boldsymbol{P}$. infestans? Different locations seem to have diverse answers to this question, and some locations have no defined answers. However, common to all locations is the apparent diversity among individuals. That mutation is the major source of significant variation is well evident in terms of the numbers of single-nucleotide polymorphisms (SNPs) when just a few diverse lineages of $P$. infestans are compared. When using genotyping by sequencing (GBS) to compare just a few dozen individuals within a recombinant progeny (Danies et al. 2014) (K. Meyers and G. Danies, unpublished data) or within a lineage ( $\mathrm{K}$. Hansen and C. Smart, unpublished data), it is not uncommon to find $10^{5}$ to $10^{6} \mathrm{SNPs}$. There are also rapid changes within clonal lineages. For example, using SSR analysis, at least three different variants have been detected within the US23 clonal lineage in the United States (K. Meyers and G. Danies, unpublished data). Preliminary studies on within-lineage variation using GBS have identified a larger number of SNPs in older lineages (US8) compared with a newer lineage such as US23 (K. Hansen and C. Smart, unpublished data). In a very early study, pathotypic analysis also revealed large differences within clonal lineages (Goodwin et al. 1995). Similar to what is now being observed with GBS, the earlier authors suggested that the older lineages had more diversity than new lineages (Goodwin et al. 1995).

In some situations, global trade is most likely responsible for the intercontinental transport of some strains, and migration has had a huge role. The detection of 13_A2 in China and India is not surprising given the global trade in seed potato. In addition to migration via seed tubers, we have now seen migration via infected tomato transplants. Some occurrences are still baffling. For example, the US8 clonal lineage was first detected in northwest Mexico and then in the United States; this linage could have been imported into the United States on plant tissues. Certainly, infected tomato fruit imported into the United States from Mexico have been observed. However, the pathway by which US8 was moved to Colombia (Vargas et al. 2009), presumably from the United States, remains a mystery. Certainly, migration affects structures of populations of other pathogens. For example, migration has been documented for other pathogens such as P. ramorum (Goss et al. 2011; Grünwald et al. 2012).

In locations such as northern Europe and central Mexico, where sexual reproduction is common, recombination appears to play a huge role in creating a very diverse population. In such locations, the influences of migration on population structure may be overwhelmed.

In other locations, where sexual reproduction plays a minor role, the rise and fall of dominant lineages remains unexplained. However, in these locations, we now realize that the one constant is the continuous turnover in clonal lineages. This turnover may be best exemplified in the United States (Fig. 6). Emergence of American and European lineages has been documented repeatedly yet we do not have a definitive understanding of the mechanism of emergence (Cooke et al. 2012). When new genotypes were first detected in northern Europe in the 1980s, there were reports that these genotypes were of greater aggressiveness than the previous population (Day and Shattock 1997). When US8 first appeared in the United States, there were also reports that it had greater aggressiveness than previous strains (Kato et al. 1997; Lambert and Currier 1997). Yet both US8 and 13_A2 have declined in prominence and we do not yet have good evidence to explain this phenomenon. One wonders if dominant lineages accumulate sufficient deleterious mutations to lose fitness.

For the United States in particular, the simple population structure enables such questions to be readily conceptualized. From whence did the recent lineages (US21, US22, US23, and US24) come? Are these lineages the result of undetected sexual recombination in the United States? Were they imported into the United States from some other location?

What controls the mating biology of $P$. infestans? Although we know much about the mating biology of $P$. infestans, much remains to be learned about what influences the frequency and outcomes of sexual recombination. Oospores form when A1 and A 2 strains are coinoculated on plant tissue, and have been detected in natural infections (Andersson et al. 1998; FernandezPavia et al. 2004; Lehtinen and Hannukkala 2004). Generation of oospores occurs on both tomato and potato leaves over a wide temperature range but reportedly only during periods of sustained high humidity (Cohen et al. 1997; Drenth et al. 1995). More oospores were produced in sprouting compared with dormant tubers (Levin et al. 2001).

Although A1 and A2 strains of P. infestans have been found near each other in many locations, only in some regions are recombinants common. This differs from the situation with some other heterothallic oomycetes such as $P$. capsici, where recombinant progeny arise frequently (Dunn et al. 2014; Lamour et al. 2012). This may be explained, in part, by the concept of population bottlenecks - where a derived population has a tiny fraction of the diversity in the source population. Sporangia of $P$. infestans are aerially dispersed but sporangia of $P$. capsici are not aerially dispersed (Granke et al. 2009). Thus, a single-season epidemic of late blight caused by $P$. infestans can be initiated by a single aerially dispersed sporangium (single mating type) being deposited on a leaf and causing infection-an extreme example of a genetic bottleneck. In contrast, long-distance dispersal of $P$. capsici is most likely via infected plant material or via infested soil or water (all of which are likely to have a diverse population of individuals). Other epidemiological and genetic factors may also restrict the occurrence of successful matings in $P$. infestans. For example, recessive mutations accumulated during long periods of exclusively asexual reproduction may lead to unviable oospores or progeny with reduced fitness. Many isolates of $P$. infestans also vary in ploidy, which may lead to genetic imbalances in their recombinants (Tooley and Therrien 1987). One study demonstrated that $3 n \times 3 n$ and $2 n \times 3 n$ crosses yielded fewer viable oospores than $2 \mathrm{n} \times 2 \mathrm{n}$ crosses (Hamed 
and Gisi 2013). Researchers have also noted that the fitness of progeny relative to their parents is often reduced, and decreased fitness is more likely when the parents vary in ploidy (Al-Kherb et al. 1995; Hamed and Gisi 2013; Klarfeld et al. 2009). Another factor that may restrict matings is the observation that some isolates preferentially infect tomato or potato (Danies et al. 2013). Combined with the fact that growing seasons or locations of the two crops may overlap only partially, the likelihood that tomatoand potato-adapted strains of opposite mating type would meet in time or space would be reduced.

There is much interest in developing a DNA assay for mating type but its molecular basis has not yet been determined in any oomycete. Mating type appears to be determined genetically by a single locus, with A1 acting as heterozygote and A2 acting as a homozygote (Fabritius and Judelson 1997). The two mating types are distinguished by their abilities to produce and respond to acyclic diterpene mating hormones named $\alpha 1$ and $\alpha 2$ (Ojika et al. 2011; Qi et al. 2005). The $\alpha 2$ hormone is made from phytol by A2 strains and metabolized to $\alpha 1$ by A1 strains, which is consistent with A1 being a heterozygote if the mating type locus encodes the relevant enzymes. Approaches based on genomics, or focusing on the enzymes that produce the hormones, hold promise for revealing the mechanism and evolution of the mating system. Heterothallism may have evolved from homothallism in oomycetes because the latter predominantly occupies its basal clades (Riethmüller et al. 2002; Thines 2014). Both homothallic and heterothallic species occur within Phytophthora and Pythium spp. and downy mildews, which suggests that heterothallism evolved multiple times in oomycetes or can revert to self fertility.

Interestingly, strongly self-fertile strains of $P$. infestans have been described in field populations (Anikina et al. 1997; Fyfe and Shaw 1992) and in progeny of laboratory crosses (Judelson 1996). These appear to be tertiary trisomics that make abundant oospores in single culture, and not heterokaryons. This distinguishes their mating systems from normal strains of $P$. infestans, which sometimes exhibit weak secondary homothallism in response to stresses such as fungicide exposure (Groves and Ristaino 2000). Oosporogenesis during stress appears to represent a temporary breakdown in the regulation of self incompatibility, as opposed to being a stable genetic change. The epidemiological impact of natural self fertility or secondary homothallism on late blight is unknown.

What factors explain fungicide resistance? As noted earlier, the reemergence of late blight in the 1980s and 1990s was due to the appearance of strains that were more aggressive and insensitive to metalaxyl (now usually sold as its active enantiomer, mefenoxam). Recently, the fraction of strains that are resistant has declined, because the vast majority in the United States since 2012 were sensitive (Hu et al. 2012; Saville et al. in press) whereas, on other continents, a mixture of sensitive and resistant strains exist (Chmielarz et al. 2014; Han et al. 2013; Klarfeld et al. 2009; Pule et al. 2013). Mefenoxam, which has strong systemic activity, maintains value even though new chemistries have appeared. Understanding the genetic basis of resistance could lead to a fast assay for the trait to aid management decisions, and reveal what processes may cause resistance to emerge against other fungicides in the future.

Studies of genetic crosses indicated that a semidominant major locus determines resistance to metalaxyl, because insensitive and sensitive parents usually yielded progeny with those phenotypes at a 1:1 ratio (Fabritius and Judelson 1997; Judelson and Roberts 1999; Lee et al. 1999). Genes influencing sensitivity to lesser degrees also segregated; hence, resistance may be considered a quantitative trait determined by one (or more) major genes plus genes of minor effect. Following a lead that metalaxyl inhibited ribosomal RNA synthesis (Davidse et al. 1988), one group implicated a tyrosine-to-phenylalanine (tyr $\rightarrow$ phe) change at amino acid 382 of the RNA polymerase 1 subunit 1 protein as a major factor in resistance (Randall et al. 2014). The existence of other genes determining insensitivity was also suggested, because not all resistant isolates contained the tyr $\rightarrow$ phe (Y382F) change and the locus did not cosegregate tightly with resistance. Consequently, a full understanding of what causes insensitivity to metalaxyl remains to be learned.

Mechanisms that influence the metalaxyl sensitivity of $P$. infestans may also affect responses to other chemistries. Isolates exhibit 10-fold or more variation in baseline sensitivity to many fungicides, including cymoxanil, dithiocarbamates, mandipropamid, and strobilurins (Daayf and Platt 2002; Grünwald et al. 2006; Judelson and Senthil 2006; Samoucha and Cohen 1984; Saville et al. 2015). Positive correlations between sensitivities to fungicides in distinct chemical classes are described in natural isolates and strains selected for resistance after UV mutagenesis (Judelson and Senthil 2006; Ziogas et al. 2006). Genes causing cross-resistance in other species include detoxifying enzymes and efflux pumps such as cytochrome $\mathrm{P} 450 \mathrm{~s}$ and $\mathrm{ABC}$ transporters, respectively (Abou Ammar et al. 2013; Bauer et al. 1999; Leroux et al. 2002). Proof that such genes are responsible for cross-resistance in $P$. infestans is lacking; however, strains adapted to growth on metalaxyl were found to express higher levels of two ABC transporters (Childers et al. 2015). In the future, changes in such genes within $P$. infestans populations may not cause total control failures but may reduce the effectiveness of fungicides or require increases in application rates. Studies in fungi (Cools et al. 2013) suggest that such changes usually have fitness costs. Whether the same is true for oomycetes, with their diploid and more plastic genomes, remains to be tested with rigor.

\section{LOOKING TO THE FUTURE}

Recent strides in rapid genotyping of $P$. infestans isolates during an epidemic within a season from locations across the United States have improved our ability to make quick and knowledgeable disease management recommendations to tomato and potato growers. Using information that is now publically available on USAblight. org, it is possible to know where reported late blight outbreaks are occurring and the clonal lineage of the pathogen causing the outbreak. Continued monitoring and genotyping of future outbreaks is critical for advanced warning of pending epidemics. This monitoring will also identify the emergence of novel linages of $P$. infestans.

Monitoring in the fairly near future will be able to take on an evolutionary approach. To date, a new clonal lineage of $P$. infestans has been named in the United States based on polymorphism for RFLP, isozyme, or SSR markers. The distinguishing feature of an evolutionary approach, incorporating genome-wide information and high-density SNP genotyping, will allow determination of whether a lineage arises by migration or by mutation, recombination, or hybridization from one or more existing clonal lineages. An evolutionary framework would allow distinction of identity by migration from identity by descent and provide new insights into what makes lineages emerge and disappear time and time again (Grünwald and Goss 2011). Another parallel aspect building on the evolutionary framework is use of whole-genome sequence data to identify effectors and adaptive genes such as RXLR effectors (as described above), mefenoxam resistance, and mating type that provide a newly emerging lineage with increased fitness (Cooke et al. 2012). Factors that contribute to the decline in prominence of a clonal lineage will be an interesting question to attack as we move forward.

Finally, the role that a changing environment will play on late blight epidemics is an important consideration. As breeders use genomic approaches to develop durable resistance against late blight in tomato and potato, it will be important to ensure that resistance holds up under a wide range of environmental conditions. Current studies tend to test resistance in a small number of environments over several years (Hansen et al. 2014), although a more powerful approach may be to test breeding lines over a wide 
geographic area covering temperate to subtropical environments with varying regional soil types and growing practices. This genotypeenvironment approach may help identify a more durable resistance. A changing environment may also modify the timing of initial inoculum of $P$. infestans present in a region, and the development of early detection strategies, including methods to detect airborne sporangia (and optimally detect fungicide sensitivity and mating type of these sporangia), will aid in disease management.

\section{CONCLUDING COMMENTS}

During the past decade, the global community working on the biology and management of $P$. infestans has learned a tremendous amount about its genomics, pathogenicity, population genetics, and evolutionary capacity and, thus, our respect for this organism as a formidable foe continues to grow. With increased globalization, we have realized that the challenges of one region can readily be transported to other regions. Now, management as well as science has close international connections. Because our early hopes of finding a "silver bullet" for management have not yet been realized, and because we have not yet been able to convert potato and tomato into nonhost plants, we need to be alert to the many factors that influence epidemics and employ all appropriate management tactics. We think that enhanced and more rapid diagnostic and genotyping technologies will contribute to better-informed management strategies, and we expect these contributions to come on line in the near future. We also fully expect to learn more about how $P$. infestans interferes with plant defenses, which could enable the discovery of new approaches to managing this pathogen. As result, we expect that, in the next review of emerging pathogens, $P$. infestans will again be included.

\section{ACKNOWLEDGMENTS}

The work reviewed here was supported by many institutions and funding agencies. Acquisition of the new data (Figures 5 through 7) was supported by our institutions and by the Agriculture and Food Research Initiative Competitive Grants Program (grant number 2011-68004-30154) from the United States Department of Agriculture.

\section{LITERATURE CITED}

Abou Ammar, G., Tryono, R., Doll, K., Karlovsky, P., Deising, H. B., and Wirsel, S. G. R. 2013. Identification of ABC transporter genes of Fusarium graminearum with roles in azole tolerance and/or virulence. PLoS One 8: e79042.

Acuna, I., Sagredo, B., Gutierrez, M., Sadoval, C., Fahrendrog, A., Secor, G., Rivera, V., and Mancilla, S. 2012. Characterization of Phytophthora infestans population in Chile. In: Thirteenth Annu. Euroblight Workshop, St. Petersburg, Russia. PPO Spec. Rep. No. 15, Wageningen, The Netherlands.

Agrios, G. N. 2005. Plant Pathology. Elsevier, San Diego, CA.

Al-Kherb, S. M., Fininsa, C., Shattock, R. c., and Shaw, D. S. 1995. The inheritance of virulence of Phytophthora infestans to potato. Plant Pathol. 44:552-562.

Andersson, B., Sandstrom, M., and Stromberg, A. 1998. Indications of soil borne inoculum of Phytophthora infestans. Potato Res. 41:305-310.

Anikina, M. I., Savenkova, L. V., and D'Yakov, Y. T. 1997. Self-fertile isolates of Phytophthora infestans. Izv. Akad. Nauk Ser. Biologicheskaya Mosc. 4: 414-418.

Anonymous. 2004. "Potatoes-Fall fungicide use." NSF Center for Integrated Pest Management. National Agricultural Statistics Service. 2001.

Armstrong, M. R., Whisson, S. C., Pritchard, L., Bos, J. I. B., Venter, E., Avrova, A. O., Rehmany, A. P., Bohme, U., Brooks, K., Cherevach, I., Hamlin, N., White, B., Fraser, A., Lord, A., Quail, M. A., Churcher, C., Hall, N., Berriman, M., Huang, S., Kamoun, S., Beynon, J. L., and Birch, P. R. J. 2005. An ancestral oomycete locus contains late blight avirulence gene Avr3a, encoding a protein that is recognized in the host cytoplasm. Proc. Natl. Acad. Sci. USA 102:7766-7771.

Bauer, B. E., Wolfger, H., and Kuchler, K. 1999. Inventory and function of yeast $\mathrm{ABC}$ proteins: About sex, stress, pleiotropic drug and heavy metal resistance. Biochim. Biophys. Acta 1461:217-236.
Berkeley, M. J. 1846. Observations, botanical and physiological, on the potato murain. J. Hortic. Soc. Lond. 1:9-34. Phytopathological Classic Number 38. American Phytopathological Society, St. Paul, MN.

Birch, P. R. J., Boevink, P. C., Gilroy, E. M., Hein, I., Pritchard, L., and Whisson, S. C. 2008. Oomycete RXLR effectors: Delivery, functional redundancy and durable disease resistance. Curr. Opin. Plant Biol. 11:373-379.

Bos, J. I., Armstrong, M. R., Gilroy, E. M., Boevink, P. C., Hein, I., Taylor, R. M., Zhendong, T., Engelhardt, S., Vetukuri, R. R., Harrower, B., Dixelius, C., Bryan, G., Sadanandom, A., Whisson, S. C., Kamoun, S., and Birch, P. R. J. 2010. Phytophthora infestans effector AVR3a is essential for virulence and manipulates plant immunity by stabilizing host E3 ligase CMPG1. Proc. Natl. Acad. Sci. USA 107:9909-9914.

Bozkurt, T.O., Schornack, S., and Win J. 2011. Phytophthora infestans effector AVRblb2 prevents secretion of a plant immune protease at the haustorial interface.Proc. Natl. Acad. Sci. USA 108:20832-20837.

Brurberg, M. B., Elameen, A., Le, V. H., Nærstad, R., Hermansen, A., Lehtinen, A., Hannukkala, A., Nielsen, B., Hansen, J., Andersson, B., and Yuen, J. 2011. Genetic analysis of Phytophthora infestans populations in the Nordic European countries reveals high genetic variability. Fungal Biol. 115:335-342.

Champouret, N., Bouwmeester, K., Rietman, H., van der Lee, T., Maliepaard, C., Heupink, A., van de Vondervoort, P. J. I., Jacobsen, E., Visser, R. G. F., van der Vossen, E. A. G., Govers, F., and Vleeshouwers, V. G. A. A. 2009. Phytophthora infestans isolates lacking class I ipiO variants are virulent on Rpi-blb1 potato. Mol. Plant-Microbe Interact. 22:1535-1545.

Childers, R., Danies, G., Myers, K., Fei, Z., Small, I. M., and Fry, W. E. 2015. Acquired resistance to mefenoxam in sensitive Isolates of Phytophthora infestans. Phytopathology 105:342-349.

Chmielarz, M., Sobkowiak, S., Debski, K., Cooke, D. E. L., Brurberg, M. B., and Sliwka, J. 2014. Diversity of Phytophthora infestans from Poland. Plant Pathol. 63:203-211.

Chowdappa, P., Kumar, N. B. J., Madhura, S., Kumar, M. S. P., Myers, K. L., Fry, W. E., Squires, J. N., and Cooke, D. E. L. 2013. Emergence of 13_A2 Blue lineage of Phytophthora infestans was responsible for severe outbreaks of late blight on tomato in south-west India. J. Phytopathol. 161: 49-58.

Chowdappa, P., Nirmal Kumar, B. J., Madhura, S., Mohan Kumar, S. P., Myers, K. L., Fry, W. E., and Cooke, D. E. L. 2015. Severe outbreaks of late blight on potato and tomato in South India caused by recent changes in the Phytophthora infestans population. Plant Pathol. 64:191-199.

Cohen, Y., Farkash, S., Reshit, Z., and Baider, A. 1997. Oospore production of Phytophthora infestans in potato and tomato leaves. Phytopathology 87: 191-196.

Cooke, D. E. L., Cano, L. M., Raffaele, S., Bain, R. A., Cooke, L. R., Etherington, G. J., Deahl, K., Farrer, R. A., Gilroy, E. M., Goss, E. M., Grünwald, N. J., Hein, I., MacLean, D., McNicol, J. W., Randall, E., Oliva, R. F., Pel, M. A., Shaw, D. S., Squires, J. N., Taylor, M. C., Vleeshouwers, V. G. A. A., Birch, P. R. J., Lees, A. K., and Kamoun, S. 2012. Genome analyses of an aggressive and invasive lineage of the Irish potato famine pathogen. PLoS Pathog. 8:e1002940.

Cools, H. J., Hawkins, N. J., and Fraaije, B. A. 2013. Constraints on the evolution of azole resistance in plant pathogenic fungi. Plant Pathol. 63(Suppl. S1): 36-42.

Daayf, F., and Platt, H. W. 2002. Variability in responses of US8 and US11 genotypes of potato and tomato isolates of Phytophthora infestans to commercial fungicides in vitro. Am. J. Potato Res. 79:433-441.

Damasceno, C. M. B., Bishop, J. G., Ripoll, D. R., Win, J., Kamoun, S., and Rose, J. K. C. 2008. Structure of the glucanase inhibitor protein (GIP) family from Phytophthora species suggests coevolution with plant endo 及-1,3-Glucanases. Mol. Plant-Microbe Interact. 21:820-830.

Danies, G., Myers, K., Mideros, M., Restrepo, S., Martin, F. N., Cooke, D. E. L., Smart, C. D., Ristaino, J. B., Seaman, A. J., Gugino, B. K., Grünwald, N. J., and Fry, W. E. 2014. An ephemeral sexual population of Phytophthora infestans in the northeastern United States and Canada. PLoS One 9:e116354.

Danies, G., Small, I. M., Myers, K., Childers, R., and Fry, W. E. 2013. Phenotypic characterization of recent clonal lineages of Phytophthora infestans in the United States. Plant Dis. 97:873-881.

Davidse, L. C., Gerritsma, O. C. M., Ideler, J., Pie, K., and Velthuis, G. C. M. 1988. Antifungal modes of action of metalaxyl, cyprofuram, benalaxyl and oxadixyl in phenylamide-sensitive and phenylamide-resistant strains of Phytophthora megasperma f. sp. medicaginis and Phytophthora infestans. Crop Prot. 7:347-355.

Day, J. P., and Shattock, R. C. 1997. Aggressiveness and other factors relating to displacement of populations of Phytophthora infestans in England and Wales. Eur. J. Plant Pathol. 103:379-391.

Deahl, K. L., Goth, R. W., Young, R., Sinden, S. L., and Gallegly, M. E. 1991. Occurrence of the A2 mating type of Phytophthora infestans in potato fields in the United States and Canada. Am. Potato J. 68:717-726. 
De Bary, M. 1863. Du developement de quelques champignons parasites. Ann. Sci. Nat. 1:143.

Dong, S., Stam, R., Cano, L. M., Song, J., Sklenar, J., Yoshida, K., Bozkurt, T. O., Oliva, R., Liu, Z., Tian, M., Win, J., Banfield, M. J., Jones, A. M. E., van der Hoorn, R. A. L., and Kamoun, S. 2014. Effector specialization in a lineage of the Irish potato famine pathogen. Science 343:552-555.

Drenth, A., Janssen, E. M., and Govers, F. 1995. Formation and survival of oospores of Phytophthora infestans under natural conditions. Plant Pathol. 44:86-94.

Dunn, A. R., Bruening, S. R., Grünwald, N. J., and Smart, C. D. 2014. Evolution of an experimental population of Phytophthora capsici in the field. Phytopathology 104:1107-1117.

Fabritius, A.-L., and Judelson, H. S. 1997. Mating-type loci segregate aberrantly in Phytophthora infestans but normal in Phytophthora parasitica: Implications for models of mating-type determination. Curr. Genet. 32: 60-65.

Fernandez-Pavia, S. P., Grünwald, N. J., Diaz-Valasis, M., Cadena-Hinojosa, M. A., and Fry, W. E. 2004. Soil-borne oospores of Phytophthora infestans in central Mexico survive winter fall and infect potato plants in the field. Plant Dis. 88:29-33.

Fry, W. E. 2008. Phytophthora infestans, the crop (and $R$ gene) destroyer. Mol. Plant Pathol. 9:385-402.

Fry, W. E., Drenth, A., Spielman, L. J., Mantel, B. C., Davidse, L. C., and Goodwin, S. B. 1991. Population genetic structure of Phytophthora infestans in the Netherlands. Phytopathology 81:1330-1336.

Fry, W. E., and Goodwin, S. B. 1997. Re-emergence of potato and tomato late blight in the United States. Plant Dis. 81:1349-1357.

Fry, W. E., McGrath, M. T., Seaman, A., Zitter, T. A., McLeod, A., Danies, G., Small, I. M., Myers, K., Everts, K., Gevens, A. J., Gugino, B. K., Johnson, S. B., Judelson, H., Ristaino, J., Roberts, P., Secor, G., Seebold, K., Snover-Clift, K., Wyenandt, A., Grünwald, N. J., and Smart, C. D. 2013. The 2009 late blight pandemic in the eastern United States-Causes and results. Plant Dis. 97:296-306.

Fyfe, A. M., and Shaw, D. S. 1992. An analysis of self-fertility in field isolates of Phytophthora infestans. Mycol. Res. 96:390-394.

Galindo, J., and Gallegly, M. E. 1960. The nature of sexuality in Phytophthora infestans. Phytopathology 50:123-128.

Gallegly, M. E., and Galindo, J. 1958. Mating types and oospores of Phytophthora infestans in nature in Mexico. Phytopathology 48:274-277.

Gavino, P. D. C. D., Smart, C. D., Sandrock, R. W., Miller, J. S., Hamm, P. B., Lee, T. Y., Davis, R. M., and Fry, W. E. 2000. Implications of sexual reproduction for Phytophthora infestans in the United States: Generation of an aggressive lineage. Plant Dis. 84:731-735.

Gilroy, E. M., Breen, S., Whisson, S., Squire, J., Hein, I., Lokossou, A., Boevink, P., Pritchard, L., Avrova, A. O., Turnbull, D., Kaczmarek, M., Cano, L., Randall, E., Lees, A., Govers, F., van West, P., Kamoun, S., Vleeshouwers, V., Cooke, D., and Birch, P. R. J. 2011. Presence/absence, differential expression and sequence polymorphisms between PiAVR2 and PiAVR2-like in Phytophthora infestans determine virulence on R2 plants. New Phytol. 191:763-776.

Gomez-Alpizar, L., Carbone, I., and Ristaino, J. B. 2007. An Andean origin of Phytophthora infestans inferred from mitochondrial and nuclear gene genealogies. Proc. Natl. Acad. Sci. USA 104:3306-3311.

Goodwin, S. B., Cohen, B. A., Deahl, K. L., and Fry, W. E. 1994a. Migration from northern Mexico was the probable cause of recent genetic changes in populations of Phytophthora infestans in the United States and Canada. Phytopathology 84:553-558.

Goodwin, S. B., Cohen, B. A., and Fry, W. E. 1994b. Panglobal distribution of a single clonal lineage of the Irish potato famine fungus. Proc. Natl. Acad. Sci. USA 91:11591-11595.

Goodwin, S. B., Sujkowski, L. S., and Fry, W. E. 1995. Rapid evolution of pathogenicity within clonal lineages of the potato late blight disease fungus. Phytopathology 85:669-676.

Goss, E. M., Larsen, M., Vercauteren, A., Werres, S., Heungens, K., and Grünwald, N. J. 2011. Phytophthora ramorum in Canada: Evidence for migration within North America and from Europe. Phytopathology 101: 166-171.

Goss, E. M., Tabima, J. F., Cooke, D. E. L., Restrepo, S., Fry, W. E., Forbes, G. A., Fieland, V. J., Cardenas, M., and Grünwald, N. J. 2014. The Irish potato famine pathogen Phytophthora infestans originated in central Mexico rather than the Andes. Proc. Natl. Acad. Sci. USA 111:8791-8796.

Granke, L. L., Windstam, S. T., Hoch, H. C., Smart, C. D., and Hausbeck, M. K. 2009. Dispersal and movement mechanisms of Phytophthora capsici sporangia. Phytopathology 99:1258-1264.

Groves, C. T., and Ristaino, J. B. 2000. Commercial fungicide formulations induce in vitro oospore formation and phenotypic change in mating type in Phytophthora infestans. Phytopathology 90:1201-1208.

Grünwald, N. J., and Flier, W. G. 2005. The biology of Phytophthora infestans at its center of origin. Annu. Rev. Phytopathol. 43:171-190.
Grünwald, N. J., and Goss, E. M. 2011. Evolution and population genetics of exotic and re-emerging pathogens: Novel tools and approaches. Annu. Rev. Phytopathol. 49:249-267.

Grünwald, N. J., Flier, W. G., Sturbaum, A. K., Garay-Serrano, E., van den Bosch, T. B. M., Smart, C. D., Matuszak, J. M., Lozoya-Saldana, H., Turkensteen, L. J., and Fry, W. E. 2001. Population structure of Phytophthora infestans in the Toluca Valley region of central Mexico. Phytopathology 91:882-890.

Grünwald, N. J., Garbelotto, M., Goss, E. M., Heungens, K., and Prospero, S. 2012. Emergence of the sudden oak death pathogen Phytophthora ramorum. Trends Microbiol. 20:131-138.

Grünwald, N. J., Sturbaum, A. K., Montes, G. R., Serrano, E. G., Lozoya-Saldana, H., and Fry, W. E. 2006. Selection for fungicide resistance within a growing season in field populations of Phytophthora infestans at the center of origin. Phytopathology 96:1397-1403.

Guo, L., Zhu, X., Hu, C., and Ristaino, J. 2010. Genetic structure of Phytophthora infestans populations in China indicates multiple migration events. Phytopathology 100:997-1006.

Haas, B. J., Kamoun, S., Zody, M. C., Jiang, R. H. Y., Handsaker, R. E., Cano, L. M., Grabherr, M., Kodira, C. D., Raffaele, S., Torto-Alalibo, T., Bozkurt, T. O., Ah-Fong, A. M. V., Alvarado, L., Anderson, V. L., Armstrong, M. R., Avrova, A., Baxter, L., Beynon, J., Boevink, P. C., Bollmann, S. R., Bos, J. I. B., Bulone, V., Cai, G., Cakir, C., Carrington, J. C., Chawner, M., Conti, L., Costanzo, S., Ewan, R., Fahlgren, N., Fischbach, M. A., Fugelstad, J., Gilroy, E. M., Gnerre, S., Green, P. J., Grenville-Briggs, L. J., Griffith, J., Grünwald, N. J., Horn, K., Horner, N. R., Hu, C.-H., Huitema, E., Jeong, D.-H., Jones, A. M. E., Jones, J. D. G., Jones, R. W., Karlsson, E. K., Kunjeti, S. G., Lamour, K., Liu, Z., Ma, L., MacLean, D., Chibucos, M. C., McDonald, H., McWalters, J., Meijer, H. J. G., Morgan, W., Morris, P. F., Munro, C. A., O’Neill, K., Ospina-Giraldo, M., Pinzon, A., Pritchard, L., Ramsahoye, B., Ren, Q., Restrepo, S., Roy, S., Sadanandom, A., Savidor, A., Schornack, S., Schwartz, D. C., Schumann, U. D., Schwessinger, B., Seyer, L., Sharpe, T., Silvar, C., Song, J., Studholme, D. J., Sykes, S., Thines, M., van de Vondervoort, P. J. I., Phuntumart, V., Wawra, S., Weide, R., Win, J., Young, C., Zhou, S., Fry, W., Meyers, B. C., van West, P., Ristaino, J., Govers, F., Birch, P. R. J., Whisson, S. C., Judelson, H. S., and Nusbaum, C. 2009. Genome sequence and analysis of the Irish potato famine pathogen Phytophthora infestans. Nature 461: 393-398.

Halterman, D. A., ChenY.,Sopee, J., Berduo-Sandoval, J., and Sanchez-Perez, A. 2010. Competition between Phytophthora infestans effectors leads to increased aggressiveness on plants containing broad-spectrum late blight resistance. PLoS One 5:e10536.

Hamed, B. H., and Gisi, U. 2013. Generation of pathogenic F1 progeny from crosses of Phytophthora infestans isolates differing in ploidy. Plant Pathol. 62:708-718.

Han, M., Liu, G., Li, J. P., Govers, F., Zhu, X. Q., Shen, C. Y., and Guo, L. Y. 2013. Phytophthora infestans field isolates from Gansu Province, China are genetically highly diverse and show a high frequency of self fertility. J. Eukaryot. Microbiol. 60:79-88.

Hannukkala, A. O., Kaukoranta, T., Lehtinen, A., and Rahkonen, A. 2007. Late-blight epidemics on potato in Finland, 1933-2002; increased and earlier occurrence of epidemics associated with climate change and lack of rotation. Plant Pathol. 56:167-176.

Hansen, Z. R., Small, I. M., Mutschler, M., Fry, W. E., and Smart, C. D. 2014. Differential Susceptibility of 39 tomato varieties to Phytophthora infestans clonal lineage US23. Plant Dis. 98:1666-1670.

Harbaoui, K., Hamada, W., Li, Y., Vleeshouwers, V. G. A. A., and van der Lee, T. 2014. Increased difficulties to control late blight in Tunisia are caused by a genetically diverse Phytophthora infestans population next to the clonal Lineage NA-01. Plant Dis. 98:898-908.

Haverkort, A. J., Boonekamp, P. M., Hutten, R., Jacobsen, E., Lotz, L. A. P., Kessel, G. J. T., Visser, R. G. F., and Van der Vossen, E. A. G. 2008. Societal costs of late blight in potato and prospects of durable resistance through cisgene modification. Potato Res. 51:47-57.

Hohl, H. R., and Iselin, K. 1984. Strains of Phytophthora infestans from Switzerland with A2 mating type behavior. Trans. Br. Mycol. Soc. 83: 529-530.

Hu, C.-H., Perez, F. G., Donahoo, R., McLeod, A., Myers, K., Ivors, K., Secor, G., Roberts, P. D., Deahl, K. L., Fry, W. E., and Ristaino, J. B. 2012. Recent genotypes of Phytophthora infestans in the eastern United States reveal clonal populations and reappearance of mefenoxam sensitivity. Plant Dis. 96:1323-1330.

Johnson, D. A., Cummings, T. F., Hamm, P. B., Rowe, R. C., Miller, J. S., Thornton, R. E., Pelter, G. Q., and Sorensen, E. J. 1997. Potato late blight in the Columbia Basin: An economic analysis of the 1995 epidemic. Plant Dis. 81:103-106.

Jones, J. D. G., and Dangl, J. L. 2006. The plant immune system. Nature 444: 323-329. 
Jones, L. R., Giddings, N. J., and Lutman, B. F. 1912. Investigations of the potato fungus, Phytophthora infestans. In: Vt. Agric. Exp. Stn. Bull. 168. University of Vermont, Burlington.

Judelson, H. S. 1996. Chromosomal heteromorphism linked to the mating type locus of the oomycete Phytophthora infestans. Mol. Gen. Genet. 252: $155-161$

Judelson, H. S., and Roberts, S. 1999. Multiple loci determining insensitivity to phenylamide fungicides in Phytophthora infestans. Phytopathology 89: 754-760.

Judelson, H. S., and Senthil, G. 2006. Investigating the role of ABC transporters in multifungicide insensitivity in Phytophthora infestans. Mol. Plant Pathol. 7:17-29.

Kamoun, S., Hraber, P., Sobral, B., Nuss, D., and Govers, F. 1999. Initial assessment of gene diversity of the oomycete pathogen Phytophthora infestans based on expressed sequences. Fungal Genet. Biol. 28:94-106.

Kamoun, S., Furzer, O., Jones, J. D. G., Judelson, H. S., Ali, G. S., Dalio, R. J. D., Roy, S. G., Schena, L., Zambounis, A., Panabières, F., Cahill, D., Ruocco, M., Figueiredo, A., Chen, X.-R., Hulvey, J., Stam, R., Lamour, K., Gijzen, M., Tyler, B. M., Grünwald, N. J., Mukhtar, M. S., Tomé, D. F. A., Tör, M., Van den Ackerveken, G., McDowell, J., Daayf, F., Fry, W. E., Lindqvist-Kreuze, H., Meijer, H. J. G., Petre, B., Ristaino, J., Yoshida, K., Birch, P. R. J., and Govers, F. 2015. The top 10 oomycete pathogens in molecular plant pathology. Mol. Plant Pathol. 16:413-434.

Kato, M., Mizubuti, E. S. G., Goodwin, S. B., and Fry, W. E. 1997. Sensitivity to protectant fungicides and pathogenic fitness of clonal lineages of Phytophthora infestans in the United States. Phytopathology 87:973-978.

King, S. R. F., McLellan, H., Boevink, P. C., Armstrong, M. A., Hall, B., Sukarta, O., Bukharova, T., Kamoun, S., Birch, P. R. J., and Banfiel, M. 2014. The Phytophthora infestans RXLR effector RD2 interacts with host MAP3Ke to suppress plant immunity related signalling. Plant Cell 26: 1345-1359.

Klarfeld, S., Rubin, A., and Cohen, Y. 2009. Pathogenic fitness of oosporic progeny isolates of Phytophthora infestans on late-blight-resistant tomato lines. Plant Dis. 93:947-953.

Lambert, D. H., and Currier, A. I. 1997. Differences in tuber rot development for North American clones of Phytophthora infestans. Am. Potato J. 74: $39-43$.

Lamour, K. H., Stam, R., Jupe, J., and Huitema, E. 2012. The oomycete broadhost-range pathogen Phytophthora capsici. Mol. Plant Pathol. 13:329-337.

Leary, W. E. 1993. New fungus blight is threatening potato crops around the world. Sunday New York Times (NATIONAL), 24 October 1993, New York.

Lee, H. A., Kim, S. Y., Oh, S. K., Yeom, S. I., Kim, S. B., Kim, M. S., Kamoun, S., and Choi, D. 2014. Multiple recognition of RXLR effectors is associated with nonhost resistance of pepper against Phytophthora infestans. New Phytol. 203:926-938.

Lee, T. Y., Mizubuti, E., and Fry, W. E. 1999. Genetics of metalaxyl resistance in Phytophthora infestans. Fungal Genet. Biol. 26:118-130.

Lees, A. K., Wattier, R., Shaw, D. S., Sullivan, L., Williams, N. A., and Cooke, D. E. L. 2006. Novel microsatellite markers for the analysis of Phytophthora infestans populations. Plant Pathol. 55:311-319.

Lehtinen, A., and Hannukkala, A. 2004. Oospores of Phytophthora infestans in soil provide an important new source of primary inoculum in Finland. Agric. Food Sci. 13:399-410.

Lehtinen, A., Hannukkala, A., Andersson, B., Hermansen, A., Le, V. H., Naerstad, R., Brurberg, M. B., Nielsen, B. J., Hansen, J. G., and Yuen, J. 2008. Phenotypic variation in Nordic populations of Phytophthora infestans in 2003. Plant Pathol. 57:227-234.

Leroux, P., Fritz, R., Debieu, D., Albertini, C., Lanen, C., Bach, J., Gredt, M., and Chapeland, F. 2002. Mechanisms of resistance to fungicides in field strains of Botrytis cinerea. Pest Manag. Sci. 58:876-888.

Levin, A., Baider, A., Rubin, E., Gisi, U., and Cohen, Y. 2001. Oospore formation by Phytophthora infestans in potato tubers. Phytopathology 91: 579-585.

Li, Y., van der Lee, T., Zhu, J. H., Jin, G. H., Lan, C. Z., Zhu, S. X., Zhang, R. F., Liu, B. W., Zhao, Z. J., Kessel, G., Huang, S. W., and Jacobsen, E. 2013. Population structure of Phytophthora infestans in China-Geographic clusters and presence of the EU genotype Blue_13. Plant Pathol. 62:932-942.

Lozano-Torres, J. L., Wilbers, R. H., Gawronski, P., Boshoven, J. C., Finkers-Tomczak, A., Cordewener, J. H., America, A. H., Overmars, H. A., Van 't Klooster, J. W., Baranowski, L., Sobczak, M., Ilyas, M., van der Hoorn, R. A., Schots, A., de Wit, P. J., Bakker, J., Goverse, A., and Smant, G. 2012. Dual disease resistance mediated by the immune receptor $\mathrm{Cf} 2$ in tomato requires a common virulence target of a fungus and a nematode. Proc. Natl. Acad. Sci. USA 109:10119-10124.

Martin, M. D., Cappellini, E., Campos, P., Samaniego, J. A., Zepeda, M. L., Campos, P. F., Seguin-Orlando, A., Wales, N., Orlando, L., Ho, S. Y. W., Dietrich, F. S., Mieczkowski, P. A., Heitman, J., Willerslev, E., Krogh, A., Ristaino, J. B., and Gilbert, M. T. P. 2013. Reconstructing genome evolution in historic samples of the Irish potato famine pathogen. Nat. Commun. 4: 2172.

Mayton, H. 2006. The soil/plant/pathogen aspects of potato late blight. Ph.D. thesis, Cornell, Ithaca, NY.

Mayton, H., Smart, C. D., Moravec, B. C., Mizubuti, E. S. G., Muldoon, A. E., and Fry, W. E. 2000. Oospore survival and pathogenicity of single oospore recombinant progeny from a cross involving the US8 and US17 lineages of Phytophthora infestans. Plant Dis. 84:1190-1196.

McLellan H., Boevink P. C., Armstrong M. R., Pritchard L., Gomez S., Morales J., Whisson S. C., Beynon J. L. and Birch P. R. J. 2013. An RxLR effector from Phytophthora infestans prevents re-localisation of two plant NAC transcription factors from the endoplasmic reticulum to the nucleus. PLoS Pathog. 9:e1003670.

Montarry, J., Andrivon, D., Glais, I., Corbiere, R., Mialdea, G., and Delmotte, F. 2010. Microsatellite markers reveal two admixed genetic groups and an ongoing displacement within the French population of the invasive plant pathogen Phytophthora infestans. Mol. Ecol. 19:1965-1977.

Niederhauser, J. S. 1956. The blight, the blighter, and the blighted. Trans. N. Y. Acad. Sci. 19:55-63.

Nishimura, R., Sato, K., Lee, W. H., Singh, U. P., and Chang, T. T. 1999. Distribution of Phytophthora infestans in seven Asian countries. Ann. Phytopathological Soc. Jpn. 65:163-170.

Oh, S.-K., Young, C., Lee, M., Oliva, R., Bozkurt, T. O., Cano, L. M., Win, J., Bos, J. I. B., Liu, H.-Y., van Damme, M., Morgan, W., Choi, D., van der Vossen, E., Vleeshouwers, V., and Kamoun, S. 2009. In planta expression screens of Phytophthora infestans RXLR effectors reveal diverse phenotypes, including activation of the Solanum bulbocastanum disease resistance protein Rpi-blb2. Plant Cell 21:2928-2947.

Ojika, M., Molli, S. D., Kanazawa, H., Yajima, A., Toda, K., Nukada, T., Mao, H., Murata, R., Asano, T., Qi, J., and Sakagami, Y. 2011. The second Phytophthora mating hormone defines interspecies biosynthetic crosstalk. Nat. Chem. Biol. 7:591-593.

Pule, B. B., Meitz, J. C., Thompson, A. H., Linde, C. C., Fry, W. E., Langenhoven, S. D., Meyers, K. L., Kandolo, D. S., van Rij, N. C., and McLeod, A. 2013. Phytophthora infestans populations in central, eastern and southern African countries consist of two major clonal lineages. Plant Pathol. 62:154-165.

Qi, J., Asano, T., Jinno, M., Matsui, K., Atsumi, K., Sakagami, Y., and Ojika, M. 2005. Characterization of a Phytophthora mating hormone. Science 309: 1828.

Randall, E., Young, V., Sierotzki, H., Scalliet, G., Birch, P., Cooke, D., Csukai, M., and Whisson, S. 2014. Sequence diversity in the large subunit of RNA polymerase I contributes to mefenoxam insensitivity in Phytophthora infestans. Mol. Plant Pathol. 15:664-676.

Randall, T. A., Dwyer, R. A., Huitema, E., Beyer, K., Cvitanich, C., Kelkar, H., Ah Fong, A. M. V., Gates, K., Roberts, S., Yatzkan, E., Gaffney, T., Law, M., Testa, A., Torto-Alalibo, T., Zhang, M., Zheng, L., Mueller, E., Windass, J., Binder, A., Birch, P. R. J., Gisi, U., Govers, F., Gow, N. A., Mauch, F., van West, P., Waugh, M. E., Yu, J., Boller, T., Kamoun, S., Lam, S. T., and Judelson, H. S. 2005. Large-scale gene discovery in the oomycete Phytophthora infestans reveals likely components of phytopathogenicity shared with true fungi. Mol. Plant-Microbe Interact. 18:229-243.

Reddick, D. 1928. Blight resistant potatoes. Phytopathology 18:483-502.

Reddick, D. 1939. Whence came Phytophthora infestans? Chron. Bot. 5: 410-412.

Riethmüller, A., Voglmayr, H., Goeker, M., Weiss, M., and Oberwinkler, F. 2002. Phylogenetic relationships of the downy mildews (Peronosporales) and related groups based on nuclear large subunit ribosomal DNA sequences. Mycologia 94:834-849.

Ristaino, J. B., Groves, C. T., and Parra, G. R. 2001. PCR amplification of the Irish potato famine pathogen from historic specimens. Nature 411:695-697.

Rodewald, J and Trognitz, B. 2013. Solanum resistance genes against Phytophthora infestans and their corresponding avirulence genes. Mol. Plant Pathol. 14:740-757.

Runno-Paurson, E., Fry, W. E., Myers, K. L., Koppel, M., and Mänd, M. 2009. Characterisation of Phytophthora infestans isolates collected from potato in Estonia during 2002-2003. Eur. J. Plant Pathol. 124:565-575.

Samoucha, Y., and Cohen, Y. 1984. Differential sensitivity to mancozeb of metalaxyl-sensitive and metalaxyl-resistant isolates of Pseudoperonospora cubensis. Phytopathology 74:1437-1439.

Saunders, D., Breen, S., Schornack, S., Win, J., Hein, I., Bozkurt, T., Champouret, N., Vleeshouwers, V., Birch, P. R. J., Gilroy, E. M., and Kamoun, S. 2012. Host protein BSL1 associates with Phytophthora infestans RXLR effector PiAVR2 and the immune receptor R2 to mediate disease resistance. Plant Cell 24:3420-3434.

Saville, A., Graham, K., Grünwald, N., Myers, K., Fry, W. E., and Ristaino, J. B. 2015. Fungicide sensitivity of US genotypes of Phytophthora infestans (Mont.) de Bary to six oomycete-targeted compounds. Plant Dis. In press. 
Scherm, H., Thomas, C. S., Garrett, K. A., and Olsen, J. M. 2014. Metaanalysis and 0ther approaches for synthesizing structured and unstructured data in plant pathology. Annu. Rev. Phytopathol. 52:453-476.

Schornack, S., van Damme, M., Bozkurt, T. O., Cano, L. M., Smoker, M., Thines, M., Gaulin, E., Kamoun, S., and Huitema, E. 2010. Ancient class of translocated oomycete effectors targets the host nucleus. Proc. Natl. Acad. Sci. USA 107:17421-17426.

Shaw, D. S., Fyfe, A. M., Hibberd, P. G., and Abdel-Sattar, M. A. 1985. Occurrence of the rare A2 mating type of Phytophthora infestans on imported Egyptian potatoes and the production of sexual progeny with A1 mating-types from the U.K. Plant Pathol. 34:552-554.

Singh, B. P., Roy, S., and Bhattacharyya, S. K. 1994. Occurrence of the A2 mating type of Phytophthora infestans in India. Potato Res. 37:227-231.

Song, J., Win, J., Tian, M., Schornack, S., Kaschani, F., Ilyas, M., van der Hoorn, R., and Kamoun, S. 2009. Apoplastic effectors secreted by two unrelated eukaryotic plant pathogens target the tomato defence protease Rcr3. Proc. Natl. Acad. Sci. USA 106:1654-1659.

Spielman, L. J., Drenth, A., Davidse, L. C., Sujkowski, L. J., Gu, W. K., Tooley, P. W., and Fry, W. E. 1991. A second world-wide migration and population displacement of Phytophthora infestans? Plant Pathol. 40: 422-430.

Sujkowski, L. S., Goodwin, S. B., Dyer, A. T., and Fry, W. E. 1994. Increased genotypic diversity via migration and possible occurrence of sexual reproduction of Phytophthora infestans in Poland. Phytopathology 84: 201-207.

Thines, M. 2014. Phylogeny and evolution of plant pathogenic oomycetesa global overview. Eur. J. Plant Pathol. 138:431-447.

Tian, M. Y., Huitema, E., da Cunha, L., Torto-Alalibo, T., and Kamoun, S. 2004. A Kazal-like extracellular serine protease inhibitor from Phytophthora infestans targets the tomato pathogenesis-related protease P69B. J. Biol. Chem. 279:26370-26377.

Tian, M. Y., Win, J., Song, J., van der Hoorn, R., van der Knaap, E., and Kamoun, S. 2007. A Phytophthora infestans cystatin-like protein targets a novel tomato papain-like apoplastic protease. Plant Physiol. 143:364-377.

Tooley, P. W., and Therrien, C. D. 1987. Cytophotometric determination of the nuclear DNA content of 23 Mexican and 18 non-Mexican isolates of Phytophthora infestans. Exp. Mycol. 11:19-26.

Torto, T. A., Li, S., Styer, A., Huitema, E., Testa, A., Gow, N. A. R., van West, P., and Kamoun, S. 2003. EST mining and functional expression assays identify extracellular effector proteins from the plant pathogen Phytophthora. Genome Res. 13:1675-1685.

van Poppel, P. M. J. A., Guo, J., van de Vondervoort, P. J. I., Jung, M. W. M., Birch, P. R. J., Whisson, S. C., and Govers, F. 2008. The Phytophthora infestans Avirulence gene Avr4 encodes an RXLR-dEER effector. Mol. Plant-Microbe Interact. 21:1460-1470.

van Poppel, P. M. J. A., Huigen, D. J., and Govers, F. 2009. Differential recognition of Phytophthora infestans races in potato R4 breeding lines. Phytopathology 99:1150-1155.

Vargas, A. M., Ocampo, L. M. Q., Cespedes, M. C., Carreno, N., Gonzalez, A., Rojas, A., Zuluaga, A. P., Myers, K., Fry, W. E., Jimenez, P., Bernal, A. J., and Restrepo, S. 2009. Characterization of Phytophthora infestans populations in Colombia: First report of the A2 mating type. Phytopathology 99:82-88.

Vetukuri, R. R., Avrova, A. K. M., Tellgren-Roth, C., Jahan, S. N., Reimegard, J., Fogelqvist, J., Savenkov, E., Söderbom, F., Avrova, A. O., Whisson, S. C., and Dixelius, C. 2012. Evidence for small RNAs homologous to effector-encoding genes and transposable elements in the oomycete Phytophthora infestans. PLoS One 7:e51399.

Vleeshouwers, V. G. A. A., and Oliver, R. 2014. Effectors as tools in disease resistance breeding against biotrophic, hemibiotrophic, and necrotrophic plant pathogens. Mol. Plant-Microbe Interact. 27:196-206.

Vleeshouwers, V. G. A. A., Raffaele, S., Vossen, J. H., Champouret, N., Oliva, R., Segretin, M. E., Rietman, H., Cano, L. M., Lokossou, A., Kessel, G., Pel, M. A., and Kamoun, S. 2011. Understanding and exploiting late blight resistance in the age of effectors. Annu. Rev. Phytopathol. 49:507-531.

Vleeshouwers, V. G. A. A., Rietman, H., Krenek, P., Champouret, N., Young, C., Oh, S.-K., Wang, M., Bouwmeester, K., Vosman, B., Visser, R. G. F., Jacobsen, E., Govers, F., Kamoun, S., and Van der Vossen, E. A. G. 2008. Effector genomics accelerates discovery and functional profiling of potato disease resistance and Phytophthora infestans avirulence genes. PLoS One 3(8):e2875.

Wangsomboondee, T., Groves, C. T., Shoemaker, P. B., Cubeta, M. A., and Ristaino, J. B. 2002. Phytophthora infestans populations from tomato and potato in North Carolina differ in genetic diversity and structure. Phytopathology 92:1189-1195.

Whisson, S. C., Boevink, P. C., Moleleki, L., Avrova, A. O., Morales, J. G., Gilroy, E. M., Armstrong, M. R., Grouffaud, S., van West, P., Chapman, S., Hein, I., Toth, I. K., Pritchard, L., and Birch, P. R. J. 2007. A translocation signal for delivery of oomycete effector proteins into host plant cells. Nature 450:115-118

Yoshida, K., Schuenemann, V. J., Cano, L. M., Pais, M., Mishra, B., Sharma, R., Lanz, C., Martin, F. N., Kamoun, S., Krause, J., Thines, M., Weigel, D., and Burbano, H. A. 2013. The rise and fall of the Phytophthora infestans lineage that triggered the Irish potato famine. eLife 2:e00731.

Yuen, J. E., and Andersson, B. 2013. What is the evidence for sexual reproduction of Phytophthora infestans in Europe? Plant Pathol. 62:485-491.

Zhang, Z., Li, Y., Tian, S., Zhu, J., Wang, J., and Song, B. 1996. The occurrence of potato late blight pathogen (Phytophthora infestans) A2 mating type in China. J. Agric. Univ. Hebei 19:62-66.

Zheng, X., Fraiture, M., Xiaoyu, L., McLellan, H., Gilroy, E., Boevink, P., Ying, C., Kandel, K., Birch, P. R. J., and Brunner, F. 2014. A subset of RXLR effectors from Phytophthora infestans suppress flg22-triggered early signalling in both Arabidopsis and tomato. PLoS Pathog. 10:e1004057.

Ziogas, B. N., Markoglou, A. N., Theodosiou, D. I., Anagnostou, A., and Boutopoulou, S. 2006. A high multi-drug resistance to chemically unrelated oomycete fungicides in Phytophthora infestans. Eur. J. Plant Pathol. 115: 283-292.

Zwankhuizen, M., Govers, F., and Zadoks, J. C. 2000. Inoculum sources and genotypic diversity of Phytophthora infestans in Southern Flevoland, The Netherlands. Eur. J. Plant Pathol. 106:667-680. 